\title{
OH LA, LA! HOW WILL THE POLARIZED DECISIONS OF THE UNITED STATES AND FRANCE REGARDING THE RESPONSIBILITY FOR POLICING TRADEMARKS ON ONLINE AUCTION SITES BE SYNTHESIZED?
}

\author{
Olivia M. Fleming*
}

\section{INTRODUCTION}

Luxurious goods are status symbols. People see a woman with a GUCCI@ handbag or a man wearing a ROLEX $®$ watch and immediately recognize that these are expensive, lavish items. Clothing, accessories, cars, electronic devices, restaurant choices, and jewelry are all material goods or services that can symbolize wealth. ${ }^{1}$ For many, it is important to be seen possessing these luxurious items. ${ }^{2}$ This is why online auction websites offering imitations of luxurious goods are enticing; why pay full price when you can get a visual status symbol for less? Unfortunately, many consumers are being duped into purchasing goods that are not "genuine." It is an unpleasant surprise to receive a fake ROLEX $\circledast$ watch in the mail, especially one looking nothing like a real ROLEX $B$ watch. The world has taken notice of the sale of counterfeit luxury goods on online auction sites, and the sale of these counterfeit products has outraged the brand owners of the genuine luxury products. $^{3}$

* Olivia M. Fleming is a J.D. Candidate for 2010 at Indiana University School of Law Indianapolis, and has a B.A. in Telecommunications from Indiana University - Bloomington. I would like to thank my husband, lan, for all of his support, my mother and brother for their encouragement, Professors Cliff Browning and Quentin Cantrell for their expertise, and Colin Koons for inspiring me to write on this topic. Most of all, I would like to dedicate this publication to my father, James Clavio, Jr., who never got a chance to read this finished note, but was instrumental in my education and whose brilliance will be missed by this world.

1. See, e.g., Dana Thomas, Excerpt: 'Deluxe: How Luxury Lost its Luster, 'NPR (Aug. 20, 2007), available at http://www.npr.org/templates/story/story.php?storyld=14185246. "The 'Luxury Goods Industry' as it is known today is a $\$ 157$ billion business that produces and sells clothes, leather goods, shoes, silks scarves and neckties, watches, jewelry, perfume and cosmetics that convey status and a pampered life-a luxurious life." Id. "Thirty-five major brands control [sixty] percent of the business, and dozens of smaller companies account for the rest. The top six brands-Louis Vuitton, Gucci, Prada, Giorgio Armani, Hermès, Chanel-have revenues in excess of $\$ 1$ billion." Id.

2. See, e.g., International Trademark Association, Anti-Counterfeiting, http://www.inta.org/index.php?option=com_content\&task=view\&id=134\&Itemid=142 \&getcontent=3 (last visited Feb. 26, 2010) ("The high levels of trademark counterfeiting in particular reflect consumers' increased desire for brand name products, the ability of counterfeiters to adapt to trends in the public appetite and the enormous profits that can be made from the sale of counterfeit goods.") [hereinafter INTA].

3. See Molly Buck Richard, Tougher Policing Requirements on Trademark Holders, TEX. 
Commercial counterfeiting is the practice of placing a fake trademark on a product, often of lesser quality, in order to make the product outwardly indistinguishable from the genuine product and intentionally deceive consumers as to its source." eBay(, Inc. ("eBay"), one of the world's largest online auctioneers, has been hit with several lawsuits claiming that its online auction website should be responsible for policing these counterfeit goods and trademarks. The charge has been that eBay should police the use of trademarks of genuine luxury goods manufactured to assure that goods sold on its auction website are not counterfeit. ${ }^{5}$ Two recent decisions, one from the United States, Tiffany Inc. v. eBay, Inc. ("Tiffany"), and one from France, Louis Vuitton Malletier v. eBay, Inc. " ("Louis Vuitton"), show a difference of international opinion as to whether online auctioneer eBay should police trademarks. France wants eBay to take preventative measures on its auction website to stop the sale of counterfeit French goods, ${ }^{8}$ while the United States believes it is the trademark owner's job to police their own brands to stop potential online counterfeiters. ${ }^{9}$ These two decisions have left the United States, France, and other countries scratching their heads about how to handle counterfeit goods on online auction sites such as eBay.

Based on these recent decisions, online auction sites find themselves free of liability in one forum, but liable in another. United States' trademark laws do not force online auction internet sites to actively search for trademark infringement. ${ }^{10}$ The trademark owner bears the principal responsibility to police and protect its brand from infringers or those producing counterfeit goods. In France, eBay was found liable for selling counterfeit French goods on eBay's French auction website and was ordered by the French court to pay sixty-one million of dollars in damages. ${ }^{11}$

LAWYER (Oct. 13, 2008), available at http://www.law.com/jsp/tx/PubArticleTX. jsp?id=1202425182603 ("No longer confined to street corners in large cities, the market for luxury knock-offs has moved on to the Internet, where it is easy for counterfeiters to sell goods online and evade prosecution.").

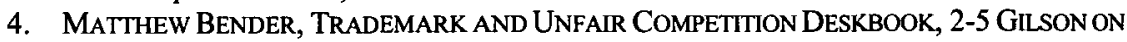
TRADEMARKS $\S 5.19(2)(2008)$ [hereinafter 2-5 GILSON ON TRADEMARKS (MB)].

5. See Tiffany Inc. v. eBay, Inc., 576 F. Supp. 2d 463 (S.D.N.Y. 2008); SA Louis Vuitton Malletier v. eBay, Inc., Tribunal de commerce [T. Com.] [Commercial Court of Paris] Paris, June 30, 2008, RG 2006077799 (Fr.), available at http:/www.qbpc.org.cn/uploads/ download/LVM\%20vs\%5B1\%5D.\%20eBay\%20Paris\%20Commercial\%20Ct\%20Decision.pdf [hereinafter Louis Vuitton].

6. See Tiffany Inc., 576 F. Supp. $2 d$ at 518.

7. See generally, Louis Vuitton, RG 2006077799, available at http://www.qbpc.org.cn/ uploads/download/LVM\%20vs\%5B1\%5D.\%20eBay\%20Paris\%20Commercial\%20Ct\%20Decis ion.pdf.

8. For another French decision involving protection of trademarked goods see Societe Hermes International v. SA eBay France and eBay International AG, Tribunal de Grande Instance [T.G.I.] [Ordinary court of original jurisdiction], Troyes, June 4, 2008, Case No. 06/02604, Slip Op. (Fr.).

9. See Tiffany Inc., 576 F. Supp. 2d at 518 (finding trademark right holders bear the principal responsibility to police their trademarks).

10. Id.

11. See Doreen Carvajal, eBay's Fake Louis Vuitton to Cost it \$61M, N.Y. TIMES (July 1, 
One possible problem that could result from these divergent opinions is an international polarization of trademark law. Some countries could begin to follow France's lead, forcing internet auction sites to police trademarks, ${ }^{12}$ while other nations impose this duty on trademark owners. ${ }^{13}$ France and the United States are not the only two countries to have divergent opinions on policing online auction sites. Both Belgium and Germany have come to opposite conclusions as well, with Belgium ruling similarly to the United States and Germany ruling similarly to France. In Belgium, L'Oreal brought a case against eBay "accusing the company of not doing enough to prevent the sale of counterfeit goods posted on its auction and sale sites."14 The Belgian commercial court ruled that the world's largest online auctioneer did not have 'a general monitoring obligation' of what is offered on its site. ${ }^{15}$ In contrast, Germany's highest court ruled that the German branch of eBay had to attempt to prevent the sale of fake Rolex watches on its auction website. ${ }^{16}$ The German court also told eBay that it "is obliged to take all reasonable and technically possible steps to ensure that fake Rolex watches are not put on auction on its site."17 Therefore, the dilemma of who should police online auction sites is not only a problem in the United States and France, but a problem affecting other countries as well. This Note will focus only on the United States and France, but will keep in mind these other decisions.

With the United States ruling for eBay and France ruling for the trademark owner, this could be the beginning of the end for a fair and open online marketplace, as auction sites struggle to follow multiple international laws to avoid being sued. The French judgment also affects free-trade on the internet, leaving open the possibility for France to begin censoring (blocking) online auction sites for fear that French citizens will buy counterfeit French goods. ${ }^{18}$ Unless the United States and France can harmonize their competing

2008), available at http://www.huffingtonpost.com/2008/07/01/ebays-fake-louis-vuitton_n 110134.html.

12. See infra notes 16-17.

13. See infra notes 14-15.

14. Agence France-Presse, eBay Claims Court Victory over L'Oreal in Fake Goods Case, PHIL. DAILY INQUIRER (Aug. 13, 2008), available at http://newsinfo.inquirer.net/ breakingnews/infotech/view/20080813-154328/eBay-claims-court-victory-over-LOreal-in-fakegoods-case. See also Valerie Walsh Johnson \& Laura P. Merritt, Tiffany v. eBay: A Case of Genuine Disparity in International Court Rulings on Counterfeit Products, LANDSLIDE, Nov./Dec. 2008 (discussing the Belgium decision and how eBay was not generally responsible for monitoring all listings and holding eBay to the standards of a normally cautious and diligent e-commerce participant).

15. Johnson \& Merritt, supra note 14.

16. Independent Online, Ebay[sic] Told to Block Fake Rolex Sales, Apr. 19, 2007, http://www.ioltechnology.co.za/article_page.php?iArticleId=3790048.

17. Id.

18. Though France has not begun blocking online auction sites like eBay, it has begun to censor certain websites. One could make the argument that France could do the same to websites that carry counterfeit goods. See, e.g., European Digital Rights, France Obtained ISPs Support in Blocking Illegal Sites, June 18, 2008, http://www.edri.org/edrigram/number6.12/ispfrance-block-sites (French Interior Minister Michel Alliot-Marie announced the French state 
auction website trademark decisions, online censorship could occur and citizens in a number of countries might find themselves blocked from online auction sites like eBay, Amazon, and Yahoo.

These decisions also affect other online auction sites that sell goods accessible around the world. Trademark owners, seeing the success of Louis Vuitton, might begin suing in European countries shown to be favorable to national trademark owners. This raises the issue of how much vetting, if any, online auction sites must do to stop counterfeit goods from being sold. Based on these polarized decisions, how will the United States and France harmonize their online auction site policies regarding trademarks to combat counterfeiting and protect consumers and trademark owners alike?

Counterfeiting is a global problem that can not be easily dismissed. Counterfeiting prevents the trademark owner's ability to guarantee quality products to its customers and hampers a consumer's ability to associate goods and services with their source. ${ }^{19}$ There is no denying that the internet provides a way to fuel counterfeiters' illegal practices by making any type of good readily available at the click of a button. The United States' failure to require eBay and other online auctioneers to ensure the authenticity of the goods sold exacerbates an already immense global problem. Though the Louis Vuitton decision was perhaps too nationalistic and harsh, the French were correct in determining that online auction sites must exert more control over the goods being sold. Online auction sites are in the best position to install measures to help combat the sale of counterfeit goods. This discussion does not condone restricting free trade, but it does encourage online auction sites such as eBay to take a few extra steps to reduce the number of counterfeit goods sold on its auction site. Though online auction sites have responsibility, trademark owners should not shift the blame solely or even principally onto these websites. Just as trademark owners spend time and money building their brand, they should also be willing to spend the money it takes to police their trademarks and protect consumers. No solution is complete, but more could be done to protect consumers in the battle against the sale of counterfeit goods.

Part one of this Note discusses the background of counterfeiting's global impact, what constitutes a counterfeit good, and background information on eBay. Part two explores the United States' and Frances' trademark laws, the Tiffany and Louis Vuitton decisions, how each country came to their diverging legal conclusions on policing online auction site trademarks, and how the trademark laws of the United States and France compare and contrast. Finally, part three discusses possible solutions to the problem of these polarized decisions and what

came to an agreement with the French ISPs to block sites carrying content related to pedophilia, terrorism, and racial hatred content. She stated that "We can no longer tolerate the sexual exploitation of children in the form of cyber-pedophilia. We have come to an agreement: the access to child pornography sites will be blocked in France. Other democracies have done it. France could wait no longer.").

19. 2-5 GILSON ON TRADEMARKS (MB), supra note $4, \S 5.19$ (1). 
can be done to further protect consumers and trademark owners alike.

\section{BACKGROUND INFORMATION ON ONLINE AUCTION SITES AND THE GLOBAL EFFECT OF COUNTERFEIT GOODS}

It is essential to harmonize online auction trademark policies between countries because online auction sites impact the global economy in a major way. ${ }^{20}$ Some of the top destinations for e-business and e-commerce trading are online auction sites. ${ }^{21}$ E-commerce trading and e-business make more than 250 online auction sites a hotbed for conducting Internet trading and business. ${ }^{22}$ The most well-established online auction sites are eBay, Yahoo, and Amazon. ${ }^{23}$ "Online auction fraud [is] the Internet-related complaint most often lodged with state and federal officials." 24 And because these companies sell the most goods, they are the most likely to be venues for internet based fraud and deceit.. ${ }^{25}$ The Consumer Reports National Research Center surveyed eBay buyers and almost half replied that they had encountered deceptions. ${ }^{26}$

The traditional retail economy is falling behind e-commerce retail sales, which is growing at about six times the rate of retail sales in the United States. ${ }^{27}$ Unfortunately, online sales of counterfeit goods are also growing at twice the rate of all online sales. ${ }^{28}$ The problem has been growing so rapidly that at least one source projected that at the current rate "counterfeit goods will outstrip the

20. Though there are other online auction sites, this Note's focus is eBay's practices because its online auction site has had the most counterfeit litigation occurring across the world. See infra notes 125-65, 182-221 and accompanying text.

21. See Mohamed S. Wahab, E-Commerce and Internet Auction Fraud: The E-Bay [sic] Community Model, Computer Crime Research Center, Apr. 29, 2004, http://www.crimeresearch.org/articles/Wahab1/.

22. Id.

23. Id.

24. Marlene Naanes, Consumer Reports: 1 in 4 New Yorkers Shopping Online Ripped off, AM N.Y. (Oct. 1, 2008), available at http://www.sun-sentinel.com/topic/am-scam1001,0 ,7437335.story?track=rss-topicgallery.

25. See Nicola Cooke, Online Auction Fraud on the Increase, Sunday Bus. Post (Apr. 8, 2007), available at 2007 WLNR 7075863 ("Online auction room fraud is on the rise, with websites such as eBay and Amazon being targeted because of their large number of users."). See also Don't Fall Prey, THE STATESMAN (June 20, 2007), available at 2007 WLNR 11506962 ("An increase in online retail sales by [twenty-six] per cent and the record-breaking number of domain-name registrations of 64.5 million have been accompanied by horrific rise in Internet crimes with online fraud complaints nearly doubling in 2003-2004 (FBI) and affecting nearly 10 million people.").

26. Winning at eBay: How to Bid Smart \& Play Safe, Consumer Reports, http://www.consumerreports.org/cro/money/shopping/shopping-tips/ebay-8-07/overview/ 0708_ebay_ov_1.htm (last visited Mar. 6, 2010).

27. Travis Brown, Protecting Brand Integrity Online: A New Approach, Manage Smarter (Dec. 21, 2007), available at http://www.trainingmag.com/msg/content_display/marketing/ e3i074b6c9d80a440503cdb4d6644646bb8.

28. Id. 
sale of legitimate goods online in 2010 about three to one." ${ }^{29}$ Thus, it is important to learn how counterfeit goods enter consumers' channels of trade and influence consumers' purchasing.

\section{A. How Counterfeiting Permeates Channels of Trade}

Consumers may have heard about counterfeit goods, but many do not know what counterfeiting actually means. Counterfeiting is the "deliberate use of a false mark that is identical with or "substantially indistinguishable" from a registered mark." ${ }^{30}$ When a trademarked good is counterfeited, ${ }^{31}$ the person using the trademark is doing so without the authorization of the trademark owner. The inclusion of "substantially indistinguishable" in the counterfeit definition is of particular importance because it allows for lower quality goods to be liable for counterfeiting by removing the requirement that the goods be identical to the trademarked good. ${ }^{32}$ The reason the mark does not need to be identical is because that would require the quality of the goods to be the same for counterfeiting to have occurred. If this were the case, merchants with low quality products could get away with copying trademarked products because the lower quality good would be distinguishable from the high quality product. ${ }^{33}$ For instance, "[W]here the genuine good is made out of metal and the cheaper copy is made out of plastic, . . . there can still be counterfeiting.",34

In order to bring a counterfeiting claim in the United States under the United States Trademark (Lanham) Act of 1946 ("Lanham Act"), a trademark owner must be federally registered with the United States Patent and Trademark Office's ("USPTO") principal register. ${ }^{35}$ Therefore, any manufacturer of a

29. Id.

30. International Trademark Association, Trade Associations, http://www.inta.org/ index.php?option=com_content\&task $=$ view $\& i d=606 \&$ Itemid $=128 \&$ getcontent $=1$ (last visited Jan. 27, 2009) ("INTA was founded in 1878. It is a not-for-profit worldwide membership organization of trademark owners and advisors. INTA's mission is to support and advance trademarks and related intellectual property ....."); See also 2-5 GILSON ON TRADEMARKS (MB), supra note 4, $\$ 5.19$ (2) (2008).

31. 2-5 GILSON ON TRADEMARKS (MB), supra note 4, $\$ 5.19$ (2)(a). "Only a limited number of marks are registered with the USPTO, so the United States trademark counterfeiting laws related are limited to a clearly defined set of genuine marks." (Comment: this quote is not at 5.19 (3)(b)(iv), is it a quote in another part of this source or a paraphrase?) Id. $\$ 5.19$ (3)(b)(iv). See also Trafficking in Counterfeit Trademarks, Service Marks, and Certification Marks-18 U.S.C. $\$ 2320$, http://www.usdoj.gov/criminal/cybercrime/ipmanual/03ipma.pdf (last visited Apr. 26, 2010) ("Examples of well-known trademarks include Kodak®, Apple®,

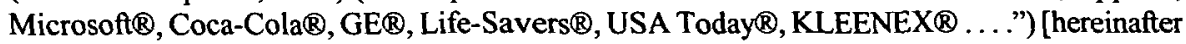
Trafficking].

32. 2-5 GILSON ON TRADEMARKS (MB), supra note 4 , at $\$ 5.19$ (3)(b)(ii).

33. Id.

34. Id. $\S 5.19(2)(\mathrm{a})$.

35. Id. $\S 5.19(2)$. "A mark is counterfeit if it is a spurious mark that is identical to or substantially indistinguishable from the plaintiff's mark where the plaintiff's mark was in use and registered on the USPTO's principal register for use on the same goods to which the defendant applied the mark." Id. at $§ 5.19(3)(\mathrm{b})$. 
good that copies a mark registered on the principal register of the USPTO can be liable for counterfeiting. ${ }^{36}$

eBay's counterfeiting woes mostly arise from sellers claiming to be selling "genuine luxury products"; when in reality, the "genuine product" is a knockoff. There is no statutory meaning of knockoff, but it is usually defined as a cheap copy intended to remind a consumer of the original product, and therefore, in many cases, knockoffs are actually counterfeit goods. ${ }^{37}$ Some knockoffs, however, are not counterfeit in the trademark sense, because they do not use a counterfeit name or label. ${ }^{38}$ Conversely, it is still possible to be found liable for counterfeiting without identically copying the product. ${ }^{39}$ By definition, an item that is counterfeit infringes on a company's trademark rights; however, it is still possible to be found liable for counterfeiting without identically copying the product. $^{40}$

In a typical counterfeiting case, unlike a trademark infringement case, the producer of the fake goods intends for the "trademark" to be nearly impossible to tell apart from the genuine article. ${ }^{41}$ When the "copy of the genuine mark is so close that an ordinary purchaser would not be able to tell the difference between fake and real, and all the other statutory criteria are met . . . a court should find that counterfeiting has taken place." 42 Another difference between counterfeiting and infringement is that counterfeiting is limited to marks registered on the principal register of the USPTO, unlike infringement, which can be for any trademark, whether on the federal registry or merely protected by common law state rights. ${ }^{43}$ Despite these differences, both counterfeiting and trademark infringement involve the likelihood that consumers will be confused about the source of the goods or service. ${ }^{44}$ Additionally, both counterfeiters and infringers benefit from the goodwill built up by the trademark owner in his brand. $^{45}$

It is important to note that a mark can only be considered counterfeit if it is precisely related to the goods or services for which the genuine good is registered, ${ }^{46}$ and "[i]t is not counterfeiting to use another's trademark on or in connection with a good that is only related to those for which the genuine mark is registered." 77 This means that if a counterfeiter used the TIFFANY® brand mark on cat food, as opposed to jewelry, that would not be considered

36. Id. at $\S 5.19(3)(\mathrm{b})$.

37. Id. at $\S 5.19(2)(b)$.

38. Id.

39. Id. at $\S 5.19$ (3)(b)(iv). Counterfeiting is tied to trademark infringement, and "all counterfeits infringe, but not all infringements are counterfeit." Id. $\S 5.19$ (2)(a).

40. Id. at $\S 5.19(2)(\mathrm{a})$.

41. Id.

42. Id.

43. Id. See 15 U.S.C. $\S 1116(\mathrm{~d})(1)(\mathrm{B})(\mathrm{i})(2008)$.

44. 2-5 GILSON ON TRADEMARKS (MB), supra note 4, at $\S 5.19$ (2)(a).

45. Id.

46. Id.

47. Id. 
counterfeit because cat food is not what Tiffany has registered on the principal registry, which is silver jewelry.

Luxury goods are particularly impacted by counterfeiting because counterfeiters unlawfully take advantage of the prestige of luxury brands, which harms those brands' tradition, identity and image. ${ }^{48}$ Since a counterfeiter is not primarily concerned with avoiding infringement, rather just making a profit, it makes sense that counterfeiters copy a mark identically in order to fool the consumer. ${ }^{49}$ The product is made to purposefully deceive the consumer as to the source of the product. ${ }^{50}$ The trademark placed on the "fake" product is outwardly indistinguishable from the genuine article. ${ }^{51}$ This purposeful deceit is what makes counterfeiting a worldwide threat to consumers, companies, and the economy.

\section{B. Why Counterfeiting is a Worldwide Threat}

Why does counterfeiting matter? In order to understand why the French and United States decisions have a major impact on the economy, it is important to look at how the sale of counterfeit goods affects jobs, transactions, and consumers. Counterfeit fraud and deception are not merely online domestic issues. Worldwide, five to seven percent of the worlds' trade is in counterfeit goods, posing a threat to global health and safety. ${ }^{52}$ It has been estimated "that 750,000 American jobs have been lost due to overseas IP [intellectual property] infringement, and that $\$ 200$ billion in U.S. sales are lost each year." 53 This problem is exacerbated when goods are sold online because of difficulties in "policing," or checking, to ensure those goods being sold are legitimately from the company listed. Counterfeiting crosses country lines through the Internet, using sites such as eBay, making it an international problem. While Customs can normally stop fake goods from entering the country at ports, it is far more difficult to police counterfeit goods on a website and stop those goods from entering the country. ${ }^{54}$

Additionally, there are serious health and safety risks associated with certain counterfeit products, such as electrical devices, pharmaceuticals,

48. LVMH, FAQ Brand Protecton, http://www.lvmh.com/fonctionalite/pg_faq_lutte.asp (last visited Apr. 26, 2010).

49. 2-5 GILSON ON TRADEMARKS (MB), supra note 4, at $\S 5.19$ (3)(b)(iv).

50. Id. at§ $5.19(2)$.

51. Id.

52. Id. §5.19 (3)(b)(vi)(2008). See The International Anticounterfeiting Coalition, Get Real -The Truth About Counterfeiting, http://www.iacc.org/counterfeiting/counterfeiting.php (last visited Apr. 26, 2010).

53. Katherine L. Tabor, IP Litigation Summer 2008 Newsletter, MondaQ (Oct. 8, 2008), available at 2008 WLNR 19297656. See also The International Anticounterfeiting Coalition, supra note 51.

54. See Trafficking, supra note 31 ("With a large number of victims across a potentially large geographic region-especially in the case of goods offered online-and small losses per victim, a large-scale counterfeiter can often evade civil sanctions."). 
automobile parts, and airplane parts. ${ }^{55}$ For example, the Federal Aviation Administration estimates that 520,000 airplane parts, or two percent of all parts installed in planes, are counterfeit. ${ }^{56}$ The Motor Equipment Manufacturers Association noted safety violations from automotive parts that were counterfeit, which is dangerous to consumers driving those cars because the quality standards in counterfeits are lower. ${ }^{57}$ Furthermore, counterfeiters do not pay taxes, child labor is often used in making counterfeit goods, and counterfeiting helps support illegal activity as profits from the sale of counterfeit goods are linked to organized crime and drug trafficking. ${ }^{58}$ With no limit to what types of goods can be counterfeited, it is easy to see how an online trading and buying website opens itself up to a potential world of illegal activity. ${ }^{59}$

A company's business and good name is threatened when it is being counterfeited or infringed. ${ }^{60}$ When consumers decide what goods to purchase, they should be able to rely on trademarks and the quality those marks represent. ${ }^{61}$ Indeed, "In the case of luxury items, such as ROLEX $®$ watches or GUCCI $@$ leather goods, failure to take action against counterfeiters can erode the status-symbol allure of these goods." ${ }^{.62}$ Technological innovations allow counterfeiters to make near-identical copies of products. ${ }^{63}$ Additionally, because products are listed online on sites like eBay, it is hard to tell the counterfeit items apart from the genuine items because the consumer is looking at a picture of the good rather than the actual product. ${ }^{64}$

A consumer who unknowingly purchases a counterfeit product, anticipating a bargain, is actually paying "an inflated price for an inferior product. $"$ "65 This threat is greatest with online auction sites because of the

55. Underwriters Laboratories, The Impact of Product Counterfeiting, http://www.ul.com/global/eng/pages/offerings/services/programs/anticounterfeitingoperations/co unterfeiting/ (last visited Apr. 26, 2010).

56. The International Anticounterfeiting Coalition, supra note 52.

57. Id. See also 3 MCCARTHY ON TRADEMARKS AND UNFAIR COMPETITION $\$ 19: 92.50$ (4th ed. 2007) (quoting U.S. v. 10,510 Packaged Computer Towers, More or Less, 152 F. Supp. 2d 1189 (N.D. Cal. 2001)) ("Counterfeit certification marks falsely imply that the merchandise has been tested and approved for safety. American consumers rely on these representations.").

58. The International Anticounterfeiting Coalition, supra note 52.

59. See Joe Pinchot, Buyer Snagged by Web Fraud; Paid Directly for Online Auction, THE HERALD (Sept. 20, 2008), available at 2008 WLNR 17906938 ("Millions of people take part in Internet auctions every day, and most of the transactions take place as they should. However, online auction fraud is the No. 1 fraud committed over the Internet, according to the National Consumers League.").

60. Emily Favre, Online Auction Houses: How Trademark Owners Pratect Brand Integrity Against Counterfeiting, 15 J.L. \& POL'Y 165, 166 (2007).

61. Trafficking, supra note 31 .

62. Mark Sommers, Taking an Aggressive Stance Against Counterfeiters: An Overview of Trademark Counterfeiting Litigation Under the Lanham Act, IP LITIGATOR (Sept./Oct. 1999), available at $\mathrm{http} / / / \mathrm{www}$.finnegan.com/resources/articles/articlesdetail.aspx?news=d0fb 159b947e-427a-b03a-e6d60cf272f5.

63. Favre, supra note 60 , at 166.

64. See id.

65. Underwriters Laboratories, supra note 55. 
volume and number of different goods being bought and sold on a daily basis. Buying a product online comes with an increased risk of anonymity. ${ }^{66}$ For instance, because eBay chooses a seller profile that is nearly anonymous, ${ }^{67}$ "intellectual property rights owners (and in particular, trademark owners) face daunting obstacles in first, uncovering the person responsible for selling counterfeit products and second, stopping their source." usually unknown, a product can only be confirmed as genuine by a consumer viewing a picture of it on his or her computer screen.

\section{The World's Largest Online Auction Website}

Ebay is at the heart of the debate over online auction site counterfeiting. eBay has described itself as "the world's largest online marketplace - where practically anyone can sell practically anything at any time." ${ }^{, 99}$ eBay started in 1995 when Pierre Omidyar wrote a code for an auction website that he ran from his home computer. ${ }^{70}$ The auction website went public in $1998 .^{71}$ More than one hundred million people around the globe now use eBay's online marketplace to either buy or sell goods. ${ }^{72}$ The users include individuals, small businesses, and enterprises that take advantage of the eBay business model and auction every type of good imaginable. ${ }^{73}$

eBay portrays itself as "an open trading platform" in which the market is the barometer of the value of the items sold. ${ }^{74}$ Its online marketplace structure enables trade on a local, national, and international basis, ${ }^{75}$ and millions of items are traded each day on eBay's online "platform." This platform is a means for parties to arrange payment and delivery between each other so that no one at eBay ever physically possesses the goods that are offered for sale;

66. See Brown, supra note 27 ("In addition, the Internet is ideally suited to protecting the anonymity of the operator behind such trade. Web sites are easy to set up, easy to take down and scam operations are easy to relocate. Local police are no match for this.").

67. See eBay, https://scgi.ebay.com/ws/eBayISAPI.dll?RegisterEnterlnfo (last visited Apr. 26,2010 ) (looking at eBay's registration page, eBay does not require an average seller to list any sensitive information, such as a driver's license number, a social security number, or any other information that is unique to an individual).

68. Actuate IP, eBay = Counterfeiter, According to French, http://www.actuateip.com.au/ wordpress/?p=11 (June 20, 2008, 12:01EST).

69. eBay, http://www.ebayinc.com/list/milestones (last visited Apr. 26, 2010) [hereinafter Milestones].

70. Id.

71. Id.

72. Leah Macpherson, Sell your stuff on eBay, Microsoft Home Magazine, http://www.microsoft.com/canada/home/life-and-style/articles/sell-your-stuff-on-ebay.aspx (last visited Apr. 26, 2010) [hereinafter Sell Your Stuff].

73. See id.

74. Milestones, supra note 69.

75. eBay, New Study Reveals 724,000 Americans Rely on eBay Sales for Income, $\mathrm{http}: / /$ investor.ebay.com/releasedetail.cfm?releaseid $=170073$ (last visited Apr. 26, 2010) [hereinafter About eBay]. 
eBay is merely a facilitator of the transaction. ${ }^{76}$ Their business model has attracted the attention of individuals and business owners alike across the world, and eBay has a large hold on the domestic and international online marketplace. $^{77}$

eBay has approximately eighty-four million users in thirty-nine markets worldwide, ${ }^{78}$ and this tremendous worldwide participation in eBay has changed the face of Internet commerce. ${ }^{79}$ In 2007 , the total value of items sold on eBay's trading platforms was nearly $\$ 60$ billion, ${ }^{80}$ meaning that "eBay users worldwide trade more than $\$ 1,900$ worth of goods on the site every second." 81 With this massive volume of trade also comes a high-risk of encountering counterfeiters. Counterfeiters create goods that look similar enough, if not identical, to original products in order to fool a consumer into purchasing the counterfeit "knock off" as an original. eBay is aware of the presence of counterfeiters on the auction website and offers the following tools, programs, and resources in order to keep consumers safe on their website: eBay Feedback, Buyer Protection, Spoof (Fraudulent) Web Site Protection, eBay Security Center, and Verified Rights Owner ("VeRO") Program. ${ }^{82}$

The main program to protect consumers and companies from fraudulent activity is the VeRO Program, which addresses listings offering potentially infringing items posted on the eBay website. ${ }^{83}$ VeRO is a notice and takedown system in which intellectual property owners can inform eBay of any listing that potentially infringes their rights, and then eBay can remove the listing. ${ }^{84}$ eBay created this program "so that intellectual property owners [could] easily report listings that infringe their rights. ${ }^{, 85}$ More than 14,000 rights owners participate

76. Anne Gilson LaLonde, Tiffany Ultimately Responsible for Protecting Its Marks, So No Contributory Infringement by eBay for Sale of Counterfeit Goods, Tiffany v. eBay, Inc., 2008 U.S. Dist. LEXIS 53359 (S.D.N.Y. 2008) (LexisNexis Expert Commentaries). See Tiffany Inc. v. eBay, Inc., 576 F. Supp. 2d 463, 474 (S.D.N.Y. 2008), finding that:

While eBay is perhaps best known for auction-style listings, sellers can also choose to sell their goods through fixed price or 'Buy It Now' listings. Sellers are responsible for setting the parameters and conditions of the sale, including the minimum acceptable bid, the Buy It Now price (if applicable), and the duration of the listing. Sellers are also responsible for the content of the listings, including the titles and descriptions of the items.

77. Sell Your Stuff, supra note 72.

78. eBay, eBay Inc. Awarded the National Medal of Technology and Innovation for Advancing Global Entrepreneurship, http://investor.ebay.com/releasedetail.cfm?releaseid $=337160$ (last visited Apr. 26, 2010).

79. Id.

80. Id.

81. Id.

82. About eBay, supra note 75 .

83. Tiffany Inc. v. eBay, Inc., 576 F. Supp. 2d 463, 478 (S.D.N.Y. 2008).

84. Tiffany Inc., 576 F. Supp. $2 d$ at 478.

85. eBay: How eBay Protects Intellectual Property (VeRO), http://pages.ebay.com/ help/tp/programs-vero-ov.html (last visited Apr. 26, 2010) [hereinafter eBay VeRO]. 
in this program. ${ }^{86}$

Despite these precautions, trademarks and goods are continually counterfeited and consumers are defrauded by purchasing items believed to be genuine. It might seem odd that a company as large as eBay would not have more effective tools in place to stop counterfeit trademarks and goods from entering channels of trade, but eBay isn't completely to blame because between constant technological innovations and a high volume of sales, counterfeiters can slip through the cracks regardless of the mechanisms in place designed to detect them.

According to United States law, trademark owners are in the best position to locate and identify counterfeits of their products because owners are far more knowledgeable about what is counterfeit than an online auction house. ${ }^{87}$ Online auction sites house hundreds and thousands of items, and they are usually unaware of the differences that set a genuine article apart from a counterfeited one. However, the French do not agree, and now the trademark world has two polarized decisions that could change the way luxury companies litigate online auction counterfeits.

\section{CURRENT UNITED STATES AND FRENCH TRADEMARK LAW}

\section{A. The French Decision}

\section{An Explanation of French Trademark Law}

In France, a trademark is a sign capable of graphic representation that serves to distinguish the goods or services of a natural or legal person. ${ }^{88}$ The rights to a mark are "acquired through registration and the use of the mark by another in any way on goods similar to those of the registration is an infringement." 1991, effective December 28, 1991. ${ }^{90}$

"[C]ommercial litigation between merchants [is] held before a Tribunal of

86. Id.

87. Favre, supra note 60 , at 170 .

88. I Alain Michelet \& ERIC Le Bellour, France $\$ 58.4$ - Trademarks Throughout THE WoRLD (Anne-Laure Covin et al. eds., 5th ed. 2008). See also JF Bretonnière and Cécile Cailac, How to Litigate Successfully in IP Matters Before the French Civil Courts, http://www.buildingipvalue.com/06EU/209_212.htm (last visited Apr. 26, 2010) ("Under French law, only the IP rights owner and/or the exclusive licensee may file an IP rights infringement action.").

89. 7 MATTHEW BENDER, FRA-WorLd TRAdEMARK LAW AND PRACTICE $\S 7.01$ (2008).

90. INTA, APPENDIX D: National Approaches to Protection of "Well-Known" Marks France, Germany, Italy, Spain, http://www.inta.org/membersonly/downloads/ref_ AppendixD.pdf (last visited Apr. 26, 2010) [hereinafter INTA National Approaches]. 
Commerce, a court specialized in commercial litigation."91 This commercial litigation extends to trademark disputes and issues revolving around counterfeit goods. Since online counterfeiting crosses country lines, the French, in order to sue defendants that sell potentially counterfeit goods to French citizens, have liberal personal jurisdiction policies that allow them to sue in France and not in the country in which the alleged infringer is located. ${ }^{92}$

In order to have jurisdiction over a defendant in France, the plaintiff must prove there is jurisdiction under Article 46 of the French Civil Procedure Code. ${ }^{93}$ Article 46 states that the plaintiff has jurisdiction to sue in the place where the damaging fact occurred or where the damage was suffered. ${ }^{94}$ In the case of websites, "the jurisprudence in Section 46 approves the criterion of accessibility of a foreign site to the French public to justify competence of French jurisdictions." 95 However, a French trademark is infringed only if the website targets the French public. ${ }^{96}$

French courts look to a number of factors to determine whether a website targets the French population. First, the court looks at the language used on the website. ${ }^{97}$ For instance, the use of a foreign language would indicate whether that website owner intended to operate in France or not. ${ }^{98}$ If the language were primarily English, the courts would probably find there to be no trademark infringement in France. ${ }^{99}$ However, if a website were entirely in French, this could lead courts to believe a company was targeting the French people. Secondly, the court can look to the availability of products and whether the website is using the contested trademarks to offer products and/or services for sale within the French territory. ${ }^{100}$ Therefore, if an online auction site is

91. Jonathon Wise Polier, French-American Commercial Litigation: How to Avoid Being Forced to Litigate in France and How to Understand French Commercial Litigation Practices, http://www.paris-law.com/articles/Fench_comercial_litigation-en.htm ( last visited Apr. 26, 2010). See also Bretonnière \& Cailac, supra note 88 ("Civil proceedings relating to trademarks are exclusively heard by a high court, as are any proceedings involving both a trademark matter and a related matter concerning copyright, industrial designs or unfair competition.").

92. See generally Louis Vuitton, Tribunal de commerce [T. Com.] [Commercial Court of Paris] Paris, June 30, 2008, RG 2006077799 (Fr.), at 5 available at http://www.qbpc.org.cn/ uploads/download/LVM\%20vs\%5B1\%5D.\%20eBay\%20Paris\%20Commercial\%20Ct\%20Decis ion.pdf.

93. Id.

94. Christian Dior Couture, SA v. eBay, Inc. and eBay International AG, Tribunal de Commerce de Paris, Première Chambre B [Paris Commercial Court], June 30, 2008, General Docket No. 2006077807 at 6 (Fr.) [hereinafter Christian Dior].

95. Id.

96. JF Bretonnière \& Cécile Cailac, Online Trademark Infringement: Key Issues Before the French Courts, http://www.buildingipvalue.com/08_EMEA/127-130BakerMcKenzie.pdf (last visited Apr. 26, 2010).

97. Id.

98. Id.

99. Id.

100. Id. "The courts may use further criteria to determine whether trademark infringement has been committed in France, including: (1) the use of the contested trademark on a website registered under the domain '.fr' (although in itself this is insufficient to find that infringement 
accessible to the French public, despite originating in a foreign country, the availability to the French public might be sufficient to justify the courts to allow French jurisdiction. ${ }^{101}$

With regard to the specific jurisdiction the Cassation Court retained over eBay, the court found that French eBay is a holding company of the eBay group $^{102}$ and was responsible for the operation of the French site, headquartered in California. ${ }^{103}$ As such, the court held eBay liable for the actions of eBay International $\mathrm{AG} .{ }^{104}$ In its findings, the court noted there was an "absence of conventional provisions between France and the United States regarding conflicts of jurisdiction, [w] hereas the Cassation Court extends the internal jurisdiction rules to international order."105 Because the alleged damage occurred in France, it did not matter that eBay was headquartered in California or in another part of the world; it is where the damage occurred, and in this instance, that damage occurred in France.

"The general principles of liability under civil law are set by Articles 1382, 1383 and 1384 of the Civil Code." 106 Article 1382 provides that one who causes damage to another is obliged to compensate for that damage. ${ }^{107}$ Article 1383 provides that every person is liable for the damage he or she causes, "not only by his intentional act, but also by his negligent conduct or by his imprudence." 108 Finally, Article 1384 provides that one is not only liable for damages created personally, but also for the acts of persons for whom he is responsible or by things in his custody. ${ }^{109}$ The main thrust of these three Articles is that if someone causes damage to another, regardless of whether it was intentional or negligent, that person is responsible for those damages and must compensate the injured party.

Even though France has general civil liability, there is a code specifically

occurred in France); (2) the inclusion of prices in a particular national currency (eg, euros); and (3) the inclusion of a French address or telephone number for contacts or the option to order products in or from France. The French courts have applied these principles to various types of website." Id.

101. SA Parfums Christian Dior, SA Kenzo Parfums, SA Parfums Givenchy, \& The Guerlin SA Corporation v. eBay Inc. and eBay International AG, Tribunal de Commerce de Paris, Première Chambre B [Paris Commercial Court], June 30, 2008, General Docket No. 2006065217 at $7(\mathrm{Fr}$.) ("And yet, they note, the advertisements in dispute, as the documents added to the arguments show, appear on foreign eBay sites, are translated into French and the products offered for sale can be delivered to France.").

102. Christian Dior, General Docket No. 2006077807 at 6 (There were five French decisions decided on the same day in the same court, so there are some facts that are interchangeable, including where eBay was considered located).

103. Id.

104. Id.

105. Id.

106. INTA National Approaches, supra note 89 ("Protection against unfair competition is provided by Articles 1382, 1383 and 1384 of the French Civil Code. French law does not provide specific protection against passing off.").

107. See id. "Any act whatever of man, which causes damage to another, obliges the one by whose fault it occurred, to compensate it." Id.

108. Id.

109. Id. 
addressing intellectual property. France's Intellectual Property Code (Le Code de la Propriété Intellectuelle, or "CPI") is dedicated to trademarks and other distinctive signs. " "While intellectual property rights are generally available in the CPI, text dealing specifically with trademark rights is found in Articles L.711-1 through L.716-16 and Articles R.712-1 through R.718-4.""11

"The French law specifically lists the acts that constitute trademark infringement" under CPI Article L.713-2 and 713-3. ${ }^{112}$ Under CPI article L.713-2, "unauthorized reproduction, use, or affixing of a mark; and the use or reproduction of marks for goods or services identical to those designated in the registration" ${ }^{, 13}$ is considered trademark infringement. Additionally, under CPI Article L.713-3, the "reproduction, use, or affixing of a mark; or use of a reproduced mark for goods or services that are similar to those designated in the registration" and the "imitation of a mark and the use of an imitated mark for goods or services that are identical or similar to those designated in the registration" 114 is prohibited. Thus, the reproduction, use, or affixing of a trademark, as well as the use of the reproduced trademark, is forbidden in the case of products or services identical to those described in the registration, except in the event of an authorization from the owner. ${ }^{115}$

Some of the world's most luxurious goods are produced in France, and thus trademarks are particularly well protected. ${ }^{116}$ The Cour de Cassation ${ }^{117}$ made specific reference that Moët Hennessy-Louis Vuitton ("LVMH") represents luxury goods and were registered French Trademarks. ${ }^{118}$ Indeed, Louis Vuitton and the LVMH brands ${ }^{119}$ are well-known trademarks, and it is understandable that French law would want to protect these marks, just as the

110. Id.

111. Terrance J. Keenan, American and French Perspectives on Trademark Keying: The Courts Leave Businesses Searching for Answers, 2 SHIDLER J. L. COM. \& TECH. 14 (2005).

112. Internet Business Law Services, France Sanctions Online Sales of Counterfeited Goods, July 7, 2008, http://www.ibls.com/internet_law_news_portal_view.aspx?id=2091\&s=latestnews.

113. Id.

114. Id.

115. Louis Vuitton, Tribunal de commerce [T. Com.] [Commercial Court of Paris] Paris, June 30, 2008, RG 2006077799 (Fr.), at 11 available at http://www.qbpc.org.cn/uploads /download/LVM\%20vs\%5B1\%5D.\%20eBay\%20Paris\%20Commercial\%20Ct\%20Decision.pdf.

116. French Law: The French Law Resource, http://www.frenchlaw.com/trade_marks.htm (last visited Apr. 26, 2010).

117. See Cour de Cassation, http://www.courdecassation.fr/about the court_9256.html (last visited June. 1, 2010) ("[t]he Court of Cassation is made up of chambers among which the appeals for consideration by the Court are distributed on the basis of varying criteria determined by the Bureau of the Court..").

118. Louis Vuitton, RG 2006077799 at 1, available at http://www.qbpc.org.cn/uploads/ download/LVM\%20vs\%5B1\%5D.\%20eBay\%20Paris\%20Commercial\%20Ct\%20Decision.pdf.

"[Louis Vuitton Malletier] is the company which, within the luxury group LMVH, designs, manufactures and markets leather goods and ready-to-wear products worldwide under the Louis Vuitton trademark." Id.

119. See Internet Business Law Services, supra note 112. 
United States offers greater protection to its famous trademarks. ${ }^{120}$ Articles L.711-4, L.714-4, and L.713-5 of the CPI specifically mention well known trademarks. ${ }^{121}$ Article L.714-4(a) and (c) of the CPI establish the criteria for "well known marks," 122 providing that a well known mark is an "earlier mark that has been registered or that is well known within the meaning of Article 6 bis of the Paris Convention for the Protection of Industrial Property" or "a trade name or signboard known throughout the national territory, where there exists a risk of confusion in the public mind." 123 The law clarifies that marks must be known by the public in general, not just those who buy the goods. ${ }^{124}$ The LVMH brands are indeed known throughout France, and if a counterfeiter were passing off his product as one of LVMH's, there would be consumer confusion as to the source or affiliation of that product.

Another CPI Article, L.713-5, is very pertinent to the Louis Vuitton case. Article L.713-5 provides that any person who uses a mark "enjoying repute for goods or services that are not similar to those designated in the registration shall be liable under civil law if such use is likely to cause a prejudice to the owner of the mark or if such use constitutes unjustified exploitation of the mark." 125 Therefore, a person or company is liable if they use a mark without permission of the owner, or if they create a lesser-quality product that is not similar to the high-quality product and would cause prejudice to the trademark holder.

\section{Le Commercial Court de Paris: Louis Vuitton Malletier v. eBay, Inc.}

eBay was sued in French Civil Court, known as the Commercial Court of Paris, on December 4, 2006, by SA Louis Vuitton Malletier, which is one of LVMH's luxury groups. ${ }^{126}$ Louis Vuitton, under the LOUIS VUITTON@ trademark, creates, manufactures, and sells leather and ready-to-wear products worldwide. ${ }^{127}$ Louis Vuitton charged eBay with failing to ensure, as its duty, that eBay's online auction site did not commit any illegal acts harmful to the Louis Vuitton name. ${ }^{128}$ Louis Vuitton claimed that eBay willingly allowed "obviously illicit" illegal listings on all of its sites, encouraged infringement,

120. See 15 U.S.C. $\$ 1125$ (explaining how the United States protects famous trademarks).

121. INTA National Approaches, supra note 90.

122. Legifrance.gouv.fr, http://www.legifrance.gouv.fr/html/codes_traduits/cpialtext.htm\# Chapter\%20I\%20Constituent\%20Elements\%20of\%20Marks (last visited Apr. 26, 2010).

123. Id.

124. See also Internet Business Law Services, supra note 112 ("The Code expressly defines a 'well known mark' as 'being known by a substantial proportion of the public and as immediately alluding the product/service to which it applies.") (internal quotations removed).

125. INTA National Approaches, supra note 90.

126. Louis Vuitton, Tribunal de commerce [T. Com.] [Commercial Court of Paris] Paris, June 30, 2008, RG 2006077799 (Fr.), at 1 available at http://www.qbpc.org.cn/uploads/ download/LVM\%20vs\%5B 1\%5D.\%20eBay\%20Paris\%20Commercial\%20Ct\%20Decision.pdf.

127. Id.

128. Id. at 2. 
and cost LVMH approximately 20 million Euros. ${ }^{129}$ eBay argued that it allowed these types of listings because the company was merely a simple website host that complied with its legal obligations as established by French Law. ${ }^{130}$ Ultimately, eBay was unsuccessful in its defense and had to pay Louis Vuitton damages for indemnificatory royalties, brand image, and nonmaterial damage. $^{131}$

According to Article 46 of the French Civil Procedure Code, jurisdiction was deemed proper because the presumed violation caused substantial prejudice to France, where Louis Vuitton is headquartered. ${ }^{132}$ Louis Vuitton claimed that eBay hosted obviously illegal advertising on all of its sites, which tended to favor trademark infringement and enormously damaged Louis Vuitton's brand and image. ${ }^{133}$ The French court system has jurisdiction to repair any trademark infringement that occurred in France on an Internet site, as long as the site is accessible to the French public; this is the case with eBay's sites. ${ }^{134}$ This ideology mirrors the European Community jurisprudence, which recognizes that the place where the damaging fact occurred indicates both the place where the damage occurred and the place of the event causing it. ${ }^{135}$ Therefore, based on a sworn statement that the French public could access the eBay sites, and that Article 46 allows a party to use the jurisdiction of the place where the damaging fact occurred or the place where the damage has been suffered, jurisdiction was deemed proper in France. ${ }^{136}$

Regarding the subject of the litigation, Louis Vuitton demonstrated to the Cassation Court that eBay "clearly" advertised the sale of products on the eBay website that described counterfeit products. ${ }^{137}$ Beginning in 1999, Louis Vuitton sent eBay repetitive warnings that counterfeit goods were available on its website. However, Louis Vuitton claims eBay did not take any measures that would efficiently fight against counterfeiting. ${ }^{138}$ Louis Vuitton gave eBay some anti-counterfeiting suggestions, such as requiring the sellers to guarantee products offered for sale are authentic, or permanently closing the account of any offender after the first violation of selling counterfeit products. ${ }^{139}$ Additionally, Louis Vuitton said that eBay sometimes allowed questionable

129. Id.

130. Id. at 8,10 .

131. Id. at 2 .

132. Louis Vuitton, Tribunal de commerce [T. Com.] [Commercial Court of Paris] Paris, June 30, 2008, RG 2006077799 (Fr.), at 5 available at http://www.qbpc.org.cn/uploads/ download/LVM\%20vs\%5B1\%5D.\%20eBay\%20Paris\%20Commercial\%20Ct\%20Decision.pdf.

133. Id.

134. Id.

135. Id.

136. Id. at 6-7.

137. Id. at 7 .

138. Louis Vuitton, Tribunal de commerce [T. Com.] [Commercial Court of Paris] Paris, June 30, 2008, RG 2006077799 (Fr.), at 7 available at http://www.qbpc.org.cn/uploads/ download/LVM\%20vs\%5B1\%5D.\%20eBay\%20Paris\%20Commercial\%20Ct\%20Decision.pdf.

139. Id. 
advertising, and did not close accounts of recurrent offenders even though trademark owners reported a violation. ${ }^{140}$ Turning a blind eye toward repeat offenders and showing a "lack of effort" to stop counterfeit activities helped convince the court that eBay "clearly" advertised the sale of counterfeit products.

eBay countered Louis Vuitton's accusations by stating that their website is a site-hoster ${ }^{141}$ that does not participate in the sale of goods between parties; eBay is merely a simple storage provider that does not participate in the content of the listing or the contracts created between the seller and the buyer. ${ }^{142}$ However, eBay was cognizant of illegal activity. French eBay claims it immediately removed advertising that was obviously illegal when reported by third parties. ${ }^{143}$ Additionally, eBay recognized that counterfeiting fraud existed and set up a system called VeRO, which is "a program helping protect intellectual property," reimbursing the users who are the victims of counterfeiting up to the limit of 150 Euros. ${ }^{144}$ Louis Vuitton chose to not join this program. ${ }^{145}$ Since November of 2006 , eBay has adopted many additional measures intended to fight counterfeiting while also maintaining "the freedom of expression" of its internet users. ${ }^{146}$

Louis Vuitton also noted that because eBay was not limited to data storage, but also performed brokerage activity, which is its main activity, that this action prohibited eBay from invoking the regime of limited responsibility, reserved by the legislation for hosting services or simple technical service providers. ${ }^{147}$ Despite eBay's plea that it was a simple host provider, the court invoked its civil liability by proclaiming that eBay operated as a firm specializing in online brokerage services. ${ }^{148}$ The court concluded eBay was a major participant in the sales on its sites and played a very active role in commercial campaigns meant to increase the number of transactions and

140. Id.

141. Id. For more detailed information on being a site-hoster in France, see id. at 10 .

142. See also Hermès International v. eBay France \& eBay International AG, Troyes Court of First Instance, Civil Chamber, June 4, 2008, RG No. 06/02604 at 6 (Fr.) (eBay claims it conducted an activity described as "brokerage of auctions conducted remotely though electronic means" in accordance with the terms of Section L. 321-3 of the Commercial Code.).

143. Louis Vuitton, RG 2006077799 at 2.

144. Id. at 10 .

145. Id. at 8. See also eBay VeRO, supra note 84.

146. Louis Vuitton, RG 2006077799 at 8.

147. Id. at 7 .

148. Id. at 10. The French court found it was obvious that $\mathrm{eBay}$ is a brokerage site and that the defending companies cannot benefit from the status of technical providers in the sense of Section 6 regarding trust in on-line trade, since they perform a commercial activity with the remuneration based on the sales of products on the auctions and, therefore, their activity is not limited to hosting of Internet sites, which would permit eBay to benefit from the provisions, applicable to hosting services only. Id. See also Philippe Boivin, EBay Wins Some (in the US [sic]), Loses Some (in France), MCCARTHY TÉTRAUlt (Aug. 8, 2008), available at http://www.mccarthy.ca/article_detail.aspx?id=4100. 
commissions it collects. ${ }^{149}$ The evidence and elements presented showed eBay was a high performance commercial brokerage service, and its hosting and brokerage services were indivisible. ${ }^{150}$ Ultimately, the court determined that "even though eBay organizes the display of the listings, eBay is not an editor of content since the content of the listings is provided by the users." same time, however, the court concluded that eBay was not just a simple host; it was also "an editor of communication services specializing in online brokerage [and,] [a]s such, eBay [did] not have an obligation to confirm that all goods sold through its services are genuine, but it [was] required to ensure that its website [would] not be used for illegal activities."

Louis Vuitton's mark was allegedly harmed from 2001 to 2006 by the prejudice caused to it by eBay's illicit behavior. ${ }^{153}$ Louis Vuitton brought forth evidence that the total commission eBay collected for the sale of their counterfeit products on its French eBay online auction site was 1.6 million Euros, and that ninety percent of products sold were counterfeit. ${ }^{154}$ Because eBay collected remuneration for each sale of counterfeit products, the illicit use of Louis Vuitton's rights harmed Louis Vuitton's image and caused moral damage. ${ }^{155}$ Contrary to Louis Vuitton's claims, eBay indicated that there was no risk of confusion between authentic Vuitton products and counterfeit Vuitton products sold on the eBay sites. ${ }^{156}$

Despite eBay's pleas, the court stated that, on a very large scale, eBay favored and amplified commercialization of counterfeit products through the online auction sale of counterfeit products. ${ }^{157}$ The court articulated that eBay had an obligation to make sure its website activity did not result in illegal acts that would cause damage to businesses. ${ }^{158}$ Additionally, the court stressed eBay

149. Louis Vuitton, RG 2006077799 at 11. See also Lewis R. Clayton, 'Tiffany v. eBay', THE NAT'L L. J. (Aug. 11, 2008), available at http://www.law.com/jsp/nlj/PubArticleNLJ.jsp?id $=1202423571347$ ("Sellers are responsible for the content of listings and the description of items; eBay does not inspect or take possession of goods. eBay charges an 'insertion fee' for each listing, and collects a 'final value fee' of $5.25 \%$ to $10 \%$ if an item is sold.") (internal quotations removed).

150. Louis Vuitton, RG 2006077799 at 11. The French court declared that "eBay Inc. and eBay International AG are not merely hosters and may not, accordingly, benefit pursuant to their status as brokers from the provisions of Article 6.1.2 of the Act dated June 21, 2004 relating to confidence in the digital economy...." Id. at 17.

151. Boivin, supra note 147.

152. Id.

153. Louis Vuitton, RG 2006077799 at 8.

154. Id.

155. Id. "[Louis Vuitton Malletier] also puts forward the existence of moral damage caused by the massive sale of infringing products on eBay's sites, gradually affecting the considerable design and quality efforts which set off the products marketed by [Louis Vuitton Malletier]." Id. at 15 .

156. Id. at 9 .

157. Id. at 11 .

158. Id. at 12. See also Boivin, supra note 148 ("[M]ere mentions in the eBay terms of use about illegal activities, which cannot be distinguished from the other terms of use ... were not 
did not fulfill its obligation to "verify that the sellers regularly performing numerous transactions on its sites are duly registered by various competent administrations, and, in France, with the Register of Businesses and Companies or the order of Trade, as well as social or other bodies." 159

This lapse in obligation aggravated the court, and it believed that eBay exercised gross negligence by its repeated violations and failure to implement any efficient technical or human solutions to prevent sale of counterfeit products on its sites. On top of that, the court believed eBay was facilitating illegal trade for the "obvious purpose" of collecting earnings and commissions from the counterfeit transactions. ${ }^{160}$ On the face of it, it appears that the French court weighed heavily against eBay on the fact that it collected commissions and profits from selling counterfeit goods.

The Court also said that eBay deliberately refused to create efficient and suitable means to fight against counterfeiting, ${ }^{161}$ such as obliging sellers to provide, upon request, a purchase bill or a certificate of authenticity of the products put on sale and found that to be an aggravating factor. Additionally, the court stated that eBay refused to permanently close the accounts of sellers found to be selling counterfeit merchandise after the first violation and to immediately withdraw illegal advertising reported by the LVMH company departments responsible for fighting against counterfeiting. ${ }^{162}$ Finally, the court commented that eBay should not be entitled to ask companies that are victims of counterfeiting on its sites to contribute financially to the fight against illegal activities committed on eBay. ${ }^{163}$ The French court was appalled that eBay would require a third party company that had no control over its website to contribute financially.

The underlying reason for the decision on the merits was that Louis Vuitton had exceptional worldwide recognition after decades of hard work, placing it among the most prestigious brands in the world. ${ }^{164}$ The French court found that "globalization of trade and appearance of new means of communication related to freedom of trade have favored commercialization of fraudulent products, including counterfeit products, which are a distortion of legal economy." 165 The court recognized that Louis Vuitton was the victim of

sufficient . eBay should have emphasized . . . in sufficient clarity, that civil and penal con sequences can be imposed on those who sell or buy counterfeits.").

159. Louis Vuitton, RG 2006077799 at 12.

160. Id. at 10. The French court stated, "Whereas, the report of a renowned expert, Mr. Maurice Nussenbaum, which, however, was not prepared adversarially, was placed in evidence in order to enlighten the Court, whereas, at the outcome of his study, such expert found, on the basis of eBay's own statistical data, that during the months of April to June 2006149,739 advertisements including the Louis Vuitton trademark were broadcast on all of the eBay sites and gave rise to 96,581 actual sales; whereas, the average price of such sales was $€ 96.50 \ldots$. " Id. at 13 .

161. Id. at 12 .

162. Id.

163. Id.

164. Id. at 9.

165. Id. 
internet commercialization of continually increasing numbers of counterfeit products, and that the sale of these products was taking place on eBay. ${ }^{166}$

This decision punished eBay for being an online auction site that could not exercise the type of proper care or control over its sellers that the French wanted, and, in the end, the nail in French eBay's coffin was that it collected commissions from the sale of counterfeit goods. This decision came down just weeks before the Tiffany decision, which came to a remarkably different conclusion.

B. The United States Decision: Tiffany Inc. v. eBay, Inc.

\section{An Explanation of the United States Trademark Act}

The Lanham Act ${ }^{167}$ is the federal statute that governs trademarks in the United States. ${ }^{168}$ The Lanham Act defines a trademark as:

any word, name, symbol, or device, or any combination thereof used by a person, or which a person has a bona fide intention to use in commerce ${ }^{169}$ and applies to register on the principal register established by this chapter, to identify and distinguish his or her goods, including a unique product, from those manufactured or sold by others and to indicate the source of the goods, even if that source is unknown. ${ }^{170}$

Trademark law includes both federal statutes and state laws and serves at least four main functions:

(1) They identify a particular seller's goods or services and distinguish them from those sold by others; (2) They signify that all goods or services bearing the mark come from or are controlled by a single source; (3) They signify that all goods or services bearing the same mark are of an equal level of quality; and (4) They serve as a primary method to advertise

166. Id.

167. The Lanham Act is codified at 15 U.S.C. $\$ 1051$ (2008).

168. 15 U.S.C. $\S 1127$ (2008). For general background information on United States trademark law, see Anne Hiaring, Basic Principles of Trademark Law, 939 PLI/PAT. 51 (2008).

169. See 15 U.S.C. $\$ 1127$ (The word commerce means all commerce which may lawfully be regulated by Congress, otherwise known as interstate commerce).

170. MatTHEW BENDER, Trademark aNd UNFAIR COMPETITION DESKBOOK, 1-2 GILSON ON TRADEMARKS $\S 2.01$ (2008). As currently defined by Section 43(a) of the Lanham Act, the term "trademark" refers to any word, name, symbol, or device, that indicates to the consumer both the source or origin of specific goods or services, and the quality associated with those goods and services. $I d$. 
and sell goods and services. ${ }^{171}$

Trademark law affords owners of a trademark exclusive right over the use of the trademark, meaning registered common law trademarks cannot be used on or in connection with a product without permission from the trademark owner. ${ }^{172}$ Under the Lanham Act, a person may apply to register their trademark at the USPTO. ${ }^{173}$

The touchstone of both common law and federal statutory trademark infringement claims is whether the manner of the defendant's use of the mark is likely to cause confusion, mistake, or deception among consumers. ${ }^{174}$ Use of a registered trademark without permission from the mark owner can result in statutory legal consequences for the unauthorized use. ${ }^{175}$ Mark owners can face financial and reputation damages if their mark is used outside of their control. ${ }^{176}$ Therefore, "the most fundamental protection afforded by the Lanham Act prevents the unauthorized use of another's trademark for the same or related goods or services, since consumer confusion, mistake, or deception is inevitable in most cases where two sources put out related goods or services under the same marks."177 Trademark law thwarts the use of identical or similar marks in a way that causes consumer confusion, mistake, or deception about the actual source of goods or services.

A trademark's main purpose is to be a source identifier that protects the investment made in a mark by its owner, thereby encouraging production of quality goods. ${ }^{178}$ Generally, the more a mark owner invests in the trademark, the more "goodwill" there is built up in the mark. ${ }^{179}$ A trademark serves as a symbol of the goodwill a business has acquired, and without the identification function performed by trademarks, buyers would have no way of returning to buy products that they prefer. ${ }^{180}$ Therefore, Section 32(i) of the Lanham Act states that if the owner of a mark desires, it can "bring a civil action against a

171. Trafficking, supra note 31. See $1 \mathrm{~J}$. Thomas McCarthy, McCarthy on Trademarks and Unfair Competition $\S 3.2$ (3rd ed. 2005).

172. Patent Office.com, http://www.patentoffice.com/trademark-law.cfm?keywords= trademark+law\&referrer=Adwords\&camp=PatentOffice\&group=trademark+law\&keyword=fren $\mathrm{ch}+$ trademark+law $\&$ traffictype $=$ search $\&$ creativeid $=858553582 \&$ sourcesite $=$ (last visited Feb . 26,2010 ).

173. Id.

174. Keenan, supra note 111.

175. Patent Office.com, supra note 172.

176. Id.

177. Brett August, Plus Ça Change .... How a French Court may have Changed Internet Advertising Forever: Google France Fined for Selling Trademarked "Keywords", 2 Nw. J. Tech. \& Intell. Prop. 5, 5-6 (2004).

178. Deborah F. Buckman, Lanham Act Trademark Infringement Actions in Internet and Website Context, 197 A.L.R. Fed. 17 (2004).

179. Id.

180. Trafficking, supra note 31. See 1 J. THOMAS MCCARTHY, MCCARTHY ON TRADEMARKS AND UNFAIR COMPETITION $§ 3.2\left(3^{\text {rd }}\right.$ ed. 2005 ). 
person alleged to have used the mark without the owners [sic] consent" if a court wants, it may grant an order authorizing the seizure of goods and counterfeit marks involved in such violation. ${ }^{182}$

Unlike French law, United States trademark law has not been as willing to hold online auction sites liable for the sale of counterfeit goods.

2. The United States Decision: Tiffany Inc. v. eBay, Inc.

Tiffany Inc., a famous jeweler that registered TIFFANY® on the Principal Register of the USPTO ${ }^{183}$ brought an action against eBay for the sale of counterfeit TIFFANY ${ }^{\circledR}$ goods being sold on eBay's website; namely, TIFFANY® silver jewelry. ${ }^{184}$ The TIFFANY® brand is renowned as a highquality, luxury good. ${ }^{185}$ The TIFFANY® marks are indisputably famous, valuable assets owned by Tiffany, and the right to use the TIFFANY® marks in U.S. commerce has become incontestable. ${ }^{186}$ Incontestability occurs when a mark owner registered on the Principal Registry has continuously used the registered mark in commerce for the goods or services listed on the registry for five consecutive years, subsequent to the date of such registration, and is still in use in commerce. ${ }^{187}$ Tiffany, in its eBay lawsuit, alleged that counterfeit TIFFANY® silver jewelry was offered on eBay's website from 2003 to 2006, and that the sale of these counterfeit goods cost Tiffany hundreds of thousands of dollars. ${ }^{188}$ Among other claims, Tiffany charged eBay with direct and contributory trademark infringement by virtue of the assistance eBay gives to the individuals that sell Tiffany products and the profits eBay receives from those members selling counterfeit products. ${ }^{189}$

181. Tiffany Inc. v. eBay, Inc., 576 F. Supp. 2d 463, 494 (S.D.N.Y. 2008). See also 15 U.S.C. $\S 1116(2008)$.

182. Tiffany Inc., 576 F. Supp. 2d at 493-94 (quoting ITC Ltd. v. Punchgini, Inc., 482 F.3d 135, 146 (2d Cir. 2007)). See also 15 U.S.C. \& 1114(1)(a)-(b) (2008), stating that: "Any person who shall, without the consent of the registrant -- (a) use in commerce any reproduction, counterfeit, copy, or colorable imitation of a registered mark in connection with the sale, offering for sale, distribution, or advertising of any goods or services on or in connection with which such use is likely to cause confusion, or to cause mistake, or to deceive; . . . shall be liable in a civil action by the registrant for the remedies hereinafter provided."

183. Tiffany Inc., $576 \mathrm{~F}$. Supp. $2 \mathrm{~d}$ at 471.

184. Id. at 469.

185. Id. at 471. "The protection of the quality and integrity of the brand and the trademarks is critical to Tiffany's success as a retailer of luxury goods." Id. at 471-72. See 15 U.S.C. § 1065 (2008) ("[T]he right of the registrant to use such registered mark in commerce for the goods or services on or in connection with which such registered mark has been in continuous use for five consecutive years subsequent to the date of such registration and is still in use in commerce, shall be incontestable ...."). See also 15 U.S.C. $§ 1052$ (f) (2008) (Substantially exclusive and continuous use of mark in commerce for 5 years preceding application for registration, as prima facie evidence that mark has become distinctive.).

186. Tiffany Inc., $576 \mathrm{~F}$. Supp. $2 \mathrm{~d}$ at 471.

187. See 15 U.S.C. $\$ 1067$ (2008).

188. Tiffany Inc., 576 F. Supp. $2 d$ at 469.

189. Id. at 470 . 
eBay denied that it helped facilitate the sale of counterfeit goods, especially with the way its business model is set up and the amount of money spent combating trademark infringement. eBay's business model is based on two components: the creation of listings and successful transactions between sellers and buyers. eBay makes its profits based on sellers' payment of an initial insertion fee and a final value fee based upon the final price for the item sold. $^{190}$ eBay does exercise control over the sellers by requiring all users to register with eBay and to sign a User Agreement forbidding users from violating any laws, third party rights, and eBay policies. ${ }^{191}$ If a user violates the agreement, the seller can be punished, which includes a warning, suspension, or expulsion. ${ }^{192}$ eBay can also restrict items being sold or listed on the auction website, and has a Trust and Safety Department, consisting of more than "[two hundred] ... individuals focus[ed] exclusively on combating infringement, at a significant cost to eBay." 193 eBay has made significant investments in anticounterfeiting initiatives and has invested around twenty million dollars each year on programs to advance safety on its website. ${ }^{194}$

In order for Tiffany (or any company) to prevail on its trademark infringement claim, Tiffany had to establish that "(1) it has a valid mark that is entitled to protection under the Lanham Act; and that (2) the defendant used the mark, (3) in commerce, (4) 'in connection with the sale ... or advertising of goods or services,' (5) without the plaintiff's consent."195 In addition, Tiffany had to prove that eBay's use of its mark was likely to cause consumer confusion, mistake, or deception as to the origin of the goods. ${ }^{196}$ Tiffany failed to meet these standards by not proving that eBay knowingly encouraged others to dilute Tiffany's trademarks and by failing to demonstrate that eBay possessed knowledge or a reason to know of specific instances of trademark infringement or dilution as required under the law. ${ }^{197}$

Taking both sides' liability into consideration, the court stated that the heart of the dispute was "who should bear the burden of policing Tiffany's valuable trademarks in Internet commerce." 198 Though eBay may have generally known that counterfeit Tiffany goods were being sold on its site, the

190. Id. at 475 . "eBay's revenue is based on sellers using eBay to list their products and successfully completing sales through eBay." Id.

191. Id. at 476.

192. Id.

193. Id.

194. Id. See also eBay, Using Authentication and Grading Services, http://pages.ebay.com/ help/buy/authentication.html (last visited Apr. 26, 2010) ("Buyers can get an item evaluated before purchasing it or get an evaluation of a recently purchased item. Sellers can boost bidder confidence by having items pre-authenticated before listing an item.").

195. Tiffany Inc., 576 F. Supp. 2d at 495 (quoting 1-800 Contacts, Inc. v. WhenU.com, Inc., 414 F.3d 400, 406-07 (2d Cir. 2005)).

196. Tiffany Inc., 576 F. Supp. 2d at 495 (quoting 1-800 Contacts, Inc., 414 F.3d at 406-07).

197. Tiffany Inc., 576 F. Supp. $2 d$ at 526 .

198. Id. at 469. 
court held that eBay was not liable for contributory trademark infringement. ${ }^{199}$ "The law [would] not impose liability for contributory trademark infringement on eBay for its refusal to take such preemptive steps in light of eBay's "reasonable anticipation" or generalized knowledge that counterfeit goods might be sold on its website." (emphasis added). ${ }^{200}$ Quite simply, the law demands more specific knowledge as to which items are infringing genuine luxury brands on eBay's online auction site and which seller is listing those items before requiring eBay to take action. ${ }^{201}$

Tiffany did acknowledge that the individual sellers, not eBay, were responsible for listing and selling the Tiffany counterfeit items. However, Tiffany believed eBay was obligated to investigate and control a seller's illegal activity. $^{202}$ The court found, "In determining whether eBay is liable, the standard is not whether eBay could reasonably anticipate possible infringement, but rather whether eBay continued to supply its services to sellers when it knew or had reason to know of infringement by those sellers."203 Therefore, the court did not use the "reasonable anticipation" standard. ${ }^{204}$ In fact, according to the court, eBay did everything in its power to stop infringers once it knew of the illegal activity.

On the other hand, the court did not believe that Tiffany did enough to stop counterfeit goods from being sold, stating that the company invested "relatively modest resources" to combat the issues. ${ }^{205}$ Three to five million of the fourteen million Tiffany budgeted over the last five years to combat counterfeiting was spent litigating this issue with eBay, and the court was unimpressed by the way Tiffany chose to spend its anti-counterfeiting money. ${ }^{206}$ Additionally, "Tiffany's time dedicated to monitoring the eBay website and preparing [Notice of Claimed Infringement forms] was limited," and it was not until 2006 that Tiffany began reporting violations on a daily basis to eBay. ${ }^{207}$ Tiffany also rejected the use of additional technology that had been suggested by eBay to help monitor and report violations, but it never attempted to develop its own technology to expedite the process of monitoring counterfeit products

199. LaLonde, supra note 76. See also Tiffany Inc., 576 F. Supp. $2 \mathrm{~d}$ at 514 ("There is no dispute that eBay was generally aware that counterfeit Tiffany jewelry was being listed and sold on eBay even prior to Tiffany's initial demand letter.").

200. Tiffany Inc., $576 \mathrm{~F}$. Supp. $2 \mathrm{~d}$ at 470.

201. Id.

202. Id. at 469 .

203. Id. at 469 (citing Inwood Labs., Inc. v. Ives Labs., Inc. 456 U.S. 844, 854 (1982)).

204. Tiffany Inc., 576 F. Supp. $2 d$ at 469 (quoting Inwood Labs., Inc. 456 U.S. at 854 n. 13

(1982)). "The standard is not whether a manufacturer 'could reasonably anticipate' possible infringement, but rather whether it knew or had reason to know that a third party is engaging in trademark infringement and continued to sell its products to that third-party." Tiffany Inc., 576 F. Supp. 2d at 503 (quoting Medic Alert Found. United States, Inc. v. Corel Corp., 43 F. Supp. 2d 933, 940 (N.D. Ill. 1999)).

205. Tiffany Inc., 576 F. Supp. $2 \mathrm{~d}$ at 484.

206. See id.

207. See id. 
on eBay. ${ }^{208}$ The court did not believe eBay's VeRO program was unduly burdensome and thought Tiffany's commitment to reporting infringing listings through the VeRO Program had been "sporadic and relatively meager.",209 In sum, Tiffany's lackluster efforts to monitor its trademark convinced the court that Tiffany's idea of "combating counterfeit sales" was suing eBay rather than through its own monitoring.

Tiffany believed that it had adequately tried to inform consumers of counterfeiting problems on eBay. eBay encouraged rights owners, as an educational tool for consumers, to create an "About Me" webpage on the eBay website to inform eBay users about their products, intellectual property rights, and legal positions. ${ }^{210}$ Tiffany took advantage of this tool and created a page in 2004, which said, "Most of the purported 'TIFFANY \& CO.' silver jewelry and packaging available on eBay is counterfeit."211 "The "About Me" page explained that genuine Tiffany merchandise is available only through stores, catalogs, and Tiffany's own website, and that the manufacture and sale of counterfeit Tiffany goods on eBay is a crime". ${ }^{212}$

Ultimately, the New York court emphasized that when a company has a trademark, it is not the job of other companies to be responsible for protecting that intellectual property. Trademark rights holders bear the primary responsibility to police their trademarks. ${ }^{213}$ Tiffany argued that because eBay could potentially screen out counterfeit TIFFANY® goods more cheaply, quickly, and effectively than Tiffany, the trademark policing burden should shift to eBay. ${ }^{214}$ According to the court, "Certainly, the evidence . . . failed to prove that eBay was a cheaper cost avoider than Tiffany with respect to policing its marks." 215 More importantly, the court also noted that, "Even if it were true that eBay is best situated to staunch the tide of trademark infringement to which Tiffany and countless other rights owners are subjected, that is not the law."216 In fact, the law states that the trademark owner is responsible, and the burden lies solely with that owner.

208. Id. at 484 .

209. Id. at 518 .

210. Id. at 479 .

211. Tiffany Inc., 576 F. Supp. $2 d$ at 479.

212. Id. at 498.

213. Id. at 518 (citing MDT Corp. v. New York Stock Exch., 858 F. Supp. 1028, 1034 (C.D. Cal. 1994) ("The owner of a trade name must do its own police work."). See also Hard Rock Cafe Licensing Corp. v. Concession Services, Inc., 955 F.2d 1143, 1149 (7th Cir. 1992) (explaining defendants are not required "to be more dutiful guardians of [trademark plaintiffs'] commercial interests".).

214. Tiffany Inc., 576 F. Supp. 2d at 518 ("[T] he corporate owners of trademarks have a duty to protect and preserve the corporation's trademark assets though vigilant policing and appropriate acts of enforcement".). See also Inwood Labs., Inc., 456 U.S. at 854 n. 13 (holding that imposing liability where manufacturers could reasonably anticipate trademark violations is a "watered down" and incorrect standard).

215. Tiffany Inc., 576 F. Supp. $2 d$ at 518.

216. Id. 
The opinion did leave open the possibility for an online auction website to be liable for trademark infringement. If any manufacturer or distributor intentionally induces a person or company to infringe a trademark or continues to offer or supply its product to a person that is known to the company to be violating trademark rights of a genuine trademark, then the manufacturer or distributor is contributorily responsible for any harm that occurs as a result of the deceit." The court emphatically stated, "Such blatant trademark infringement inhibits competition and subverts both goals of the Lanham Act. By applying a trademark to goods produced by one other than the trademark's owner, the infringer deprives the owner of the goodwill which he spent energy, time, and money to obtain."218 However, because eBay did take reasonable steps to subvert the malfeasance of trademark infringers, the court was very reluctant to place any liability on eBay.

This decision did not remove eBay from all potential liability because "eBay [does] have a legal obligation, once it [knows] of specific instances of counterfeiting, to stop those sales." ${ }^{219}$ Nevertheless, just because eBay had that obligation did not mean that Tiffany could abandon its responsibility to alert eBay to potentially infringing listings. ${ }^{220}$ Once sufficient efforts had been made by eBay to eliminate listings that it knew or had reason to know offered counterfeits, "Tiffany bore the burden to stop the sales of any other, more nonobvious counterfeits, those that eBay could not otherwise know or have reason to know were infringing.",221

Tiffany was aware of the Louis Vuitton judgment at the time its lawsuit against eBay was being heard. ${ }^{222}$ In a letter addressed to the court, Tiffany requested the New York court to recognize the decision issued on July 3, 2008, by the Commercial Court of Paris, France, and "give preclusive effect to factual determinations made therein."223 However, for reasons not stated, Tiffany withdrew its request. ${ }^{224}$ This note is the first indication that the United States court knew of the Louis Vuitton decision and consciously disregarded the Commercial Court of Paris' factual and legal determinations grounding the Tiffany decision solely in U.S. law.

217. Inwood Labs., Inc., 456 U.S. at 854 (footnote omitted).

218. Id. at $855 \mathrm{n} .14$.

219. Anne Gilson LaLonde, Gilson LaLonde on Tiffany Ultimately Responsible for Protecting its Marks, So No Contributory Infringement by eBay for Sale of Conterfeit Goods: Tiffany, Inc. v. eBay, Inc., Dec. 12, 2008, http://law.lexisnexis.com/practiceareas/Insights-Analysis/Counterfeiting/FREE-DOWNLOAD-Gilson-LaLonde-on-Tiffany-Ultimately-

Responsible-for-Protecting-its-Marks-So-No-Contributory-Infringement-by-eBay-for-Sale-ofConterfeit-Goods-Tiffany-Inc-v-eBay-Inc.

220. Id.

221. Id.

222. Tiffany Inc., 576 F. Supp. 2 d at 471.

223. Id.

224. Id. "A conference regarding this request was held with the Court on July 8, 2008.

Tiffany subsequently withdrew the request by letter dated July 9,2008 ." Id. 


\section{Differences Between French and United States Trademark Law}

The main difference between French and United States trademark law is the seemingly nationalistic nature of the French trademark system. In France, the "co-existing system combining Community-wide trademark rights and territorially-based national trademark rights are similar, but only in a general sense, to the trademark system in the United States." ${ }^{225}$ Unlike the United States, France treats trademark rights similar to property rights. ${ }^{226}$ French Intellectual Property Code, Article L. 713-2 "provides that a trademark is infringed, even where there is no likelihood of confusion", when "(1) defendant reproduces the characteristic elements of the mark, or (2) defendant uses the mark in any act of commercial competition conducted with a counterfeit mark." 227 Also, both the United States and French trademark law are concerned with the trademark owners' goodwill and reputations, which require investment of financial and intellectual resources. ${ }^{228}$ However, the French may find infringement even in the absence of likelihood of confusion. ${ }^{229}$

Beyond each country's own trademark laws, France and the United States are also bound to other states or treaties. The French, besides having national trademark laws, are bound to the rules of the European Union and treaties to which France is signatory. ${ }^{230}$ "Trademark rights are limited territorially and the applicable law depends on each national or regional regulation."231 For instance, "the owner of a French trademark cannot prevent the use and/or registration of its trademark by a third party outside France if it does not own foreign trademarks. ${ }^{, 232}$ Also, the United States system provides for nationwide registration under the Lanham Act, yet acknowledges state-granted registrations. $^{233}$

Another distinction is that United States "law and public policy tend to favor consumer welfare and freedom of competition."234 "This difference is reflected . . . in the stark contrast between France's restrictive attitude toward comparative advertising and America's far more permissive stance .... [T]

225. Keenan, supra note 111.

226. Patrick F. Nevins, Is Google ${ }^{\mathrm{TM}}$ Doing Evil with Trademarks?, 40 CONN. L. REV. 247, 265 (2007) ("[T]rademark rights are not property rights in gross, but limited entitlements to protect against uses that diminish the informative value of marks.") (quoting Stacy L. Dogan \& Mark A. Lemly, Trademarks and Consumer Search Costs on the Internet, 41 Hous. L. REV. 777, 805 (2004)). See also MichELET \& BELlouR, supra note 87, at $§ 58$ ("Registration of a mark confers on its owner a right of property in that mark for the goods and services designated in the application.").

227. Keenan, supra note 111.

228. Id.

229. Id.

230. Id.

231. Bretonnière \& Cailac, supra note 96.

232. Id.

233. Keenan, supra note 111.

234. Id. 
recent decisions illustrate some of the issues that businesses face in this developing area."235 This difference has mostly been litigated in regard to search engines and keyword advertising. ${ }^{236}$

The United States and French trademark infringement laws do share some similarities, namely consumer protection where there is a likelihood of consumer confusion, mistake, or deception. ${ }^{237}$ For instance, French Article L.313-3 provides that a trademark is infringed where there is a likelihood of confusion $^{238}$ and "(1) defendant reproduces a mark for products or services similar to those listed in the trademark registration, or (2) defendant imitates a trademark or uses an imitated trademark for goods and services that are identical or similar to those listed in the trademark registration."239 Under the Lanham Act, the United States is also concerned with the likelihood of confusion, mistake, or deception as to the source, sponsorship, affiliation, or endorsement of a good or service. ${ }^{240}$

Despite any similarities in trademark law, the Tiffany and Louis Vuitton judgments clearly amplify differences between the two countries' views regarding online auction site trademark infringement and how future litigations might be handled in each respective country.

\section{ANALYSIS OF HOW THESE DECISIONS MIGHT AFFECT EUROPEAN AND UNITED STATES LITIGATION}

\section{A. Was the United States or French Trademark Decision "Correct"?}

It is important to consider the merits of both the United States and French trademark judgments. Both decisions carry important information about the way these two countries view trademarks and the amount of responsibility necessary to maintain a trademark brand. So, is one decision more "correct" than the other, or can United States and French trademark law learn from each other to create a more uniform global approach to policing trademarks on online auction sites?

235. Id.

236. See, e.g., Alex Bainbridge, Is UK Trademark Law more Similar to US [sic] or French Trademark Law?, May 23, 2008, http://www.tourcms.com/blog/2008/05/23/is-uk-trademarklaw-more-similar-to-us-or-french-trademark-law/ ("The Lower Court of Nanterre required Google France to pay 70,000 euros (about $\$ 81,400$ ) to two companies that owned the rights to certain words. Google France sold the use of these words to advertisers through its AdWords program.").

237. Keenan, supra note 111.

238. Id.

239. Id.

240. See 15 U.S.C. $\$ 1125$. 


\section{Why the United States Decision was Correct}

Why should a company be responsible for monitoring another's trademark rights? This is a major question raised by Tiffany Inc. v. eBay, Inc. ${ }^{241}$ The Lanham Act does not shift the burden for policing trademarks from one who owns the mark to one that facilitates the sale of goods (or services) in association with that mark. ${ }^{242}$ The primary goal of United States trademark law is to protect consumers from confusion, mistake, or deception about the source or sponsorship or affiliation of goods and services, ${ }^{243}$ not for a non-trademark owner to seek out and prevent trademark violations. ${ }^{244}$ Though the French are concerned with protecting consumers, the Louis Vuitton decision did not appear to be as concerned with consumers as it did with protecting and limiting damage to the trademark owner.

eBay does not believe that LVMH is at all concerned about its consumers. In fact, eBay stated, "If counterfeits appear on [eBay's] site, we take them down swiftly," ${ }^{245}$ meaning eBay is dedicated to protecting consumers from counterfeit goods by removing them as quickly as possible. eBay also said that the ruling is not about counterfeiting as much as an attempt by LVMH "to protect uncompetitive commercial practices at the expense of consumer choice and the livelihood of law-abiding sellers that eBay empowers every day."246 eBay's position was that the French court was more concerned about its wellknown trademark brands, and less about consumers and legitimate sellers on its French eBay online auction site.

Additionally, making online auction sites police the trademarks of other companies has many unintended consequences. Companies that trade branded products would be potentially banned from accurately describing products by their brand name, even though this has been proven to be within the boundaries of trademark law in the United States. ${ }^{247}$ Besides difficulties in finding

241. Tiffany Inc. v. eBay, Inc., 576 F. Supp. 2d 463, 469 (S.D.N.Y. 2008).

242. See generally 15 U.S.C. $\$ 1051$.

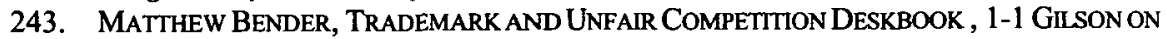
TRADEMARKS $\S 1.03$ (2008).

244. Tiffany Inc., 576 F. Supp. 2d at 515 (citing Hard Rock Cafe Licensing Corp., 955 F.2d at 1149 , which held that there is "no affirmative duty to take precautions against the sale of counterfeits. Although the 'reason to know' part of the standard for contributory liability requires [the defendant] to understand what a reasonably prudent person would understand, it does not impose any duty to seek out and prevent violations.").

245. Henry Samuel, Counterfeit Luxury Goods Cost eBay \$61.7 Million in Damages, THE DAILY TELEGRAPH (July 1, 2008), available at http://www.nysun.com/style/counterfeit-luxurygoods-cost-ebay-617-million/80993/. See also Carvajal, supra note 11.

246. Cnn.com, eBay fined $\$ 63 \mathrm{~m}$ Over Fake Luxury Goods, July 1, 2008, http://www.cnn.com/2008/BUSINESS/06/30/louis.vuitton/index.html. See also Carvajal, supra note 11.

247. See Tiffany Inc., 576 F. Supp. 2d at 473-74 (quoting Dow Jones \& Co. v. Int'l Sec. Exch., Inc., 451 F.3d 295, 308 (2d Cir. N.Y. 2006)), finding that:

While a trademark conveys an exclusive right to the use of a mark in commerce in the area reserved, that right generally does not prevent one who trades a 
counterfeit sellers, eBay would have to contend with complex international jurisdictional and enforcement issues. ${ }^{248}$ "Making eBay definitively responsible for the sale of counterfeit products merely reduces the efficiency of its business model and may lead to resentment towards active litigants from consumers who use eBay for legitimate trading."249

Even the French are a bit shocked by the results of the LVMH decision. ${ }^{250}$ Alexandra Neri, head of Intellectual Property for Herbert Smith, stated, "From a legal point of view the judgment doesn't make any sense. Before this decision eBay obtained 18 others that said the company wasn't liable." ${ }^{251}$ Because the French are so protective of intellectual property rights, especially of famous brands, ${ }^{252}$ the decision has seemingly become too nationalistic, protecting brand owners at the expense of free trade and consumer choice.

eBay is acutely aware of the counterfeit sales and has taken measures on its website to combat the issue. eBay provides intellectual property rights owners, through its VeRO program, the opportunity to report, and have eBay remove, listings on the site that infringe on their rights. ${ }^{253}$ Although reporting violations requires constant monitoring by intellectual property rights owners, especially since millions of sales go through eBay, it is much cheaper than suing eBay and asking eBay to do the same type of monitoring. ${ }^{254}$ It is more advantageous for intellectual property rights owners to retain control of reporting violations, because if they do not eBay would have to "pull every suspect listing even if to do so would be detrimental to the reputation of the

branded product from accurately describing it by its brand name, so long as the trader does not create confusion by implying an affiliation with the owner of the product.

248. Actuate IP, supra note 66.

249. Id.

250. See Ben Moshinsky, French Court Hits eBay with $640 \mathrm{~m}$ in Fines for Trading in Counterfeits, THE LAWYER (July 7, 2008), available at http://www.intangiblebusiness.com/ store/data/files/419-Ebay_fined_for_counterfeits_The_Lawyer_7_July_2008.pdf. See also Counterfeiting on the Internet - [e]Bay held Jointly Responsible for the sale of Counterfeit Goods for the First time in France, http://bakerxchange.com/ve/ZZ6790g8661U62mQ27923 (last visited Feb. 26, 2010), which commented that:

This constitutes a major turn in French case-law since the previous decisions ruling on similar cases did not convict eBay or other auctions platforms on the basis that they were merely "technical intermediaries" and/or "hosting services providers". Indeed, pursuant to French law, Courts ruled that eBay as a hosting services provider had neither the obligation nor the possibility to control the contents of its websites and had no responsibility in this respect except in very specific circumstances....

251. Moshinsky, supra note 250.

252. See Louis Vuitton, Tribunal de commerce [T. Com.] [Commercial Court of Paris] Paris, June 30, 2008, RG 2006077799 (Fr.), at 9, available at http://www.qbpc.org.cn/uploads/ download/LVM\%20vs\%5B1\%5D.\%20eBay\%20Paris\%20Commercial\%20Ct\%20Decision.pdf (finding that Louis Vuitton had exceptional worldwide recognition after decades of hard work, placing them among the most prestigious brands in the world).

253. Actuate IP, supra note 68.

254. Id. 
intellectual property rights owner."255 It would be a great detriment to force online auction sites to monitor trademarks, because it gives the mark owner free reign to stop diligently policing their trademark and blame another entity for counterfeiting problems. Notably, the New York court stated that even though eBay might have known of past infringements, that should not mean that trademark owners can use that generalized knowledge as ammunition to force eBay into prospectively policing its online auction site to prevent any future infringements. $^{256}$

Communication has been globally expanded thanks to online sales. However, "if intermediaries have to take on the burden of policing trademarks, many internet service providers will take the easy route and remove any posting that is even remotely suspicious. That would effectively quash the extraordinary growth of online commerce and speech." 257 Forcing online auctions to police trademarks could expand the trademark legal regime and threaten the success and viability of online auction site businesses and e-commerce generally. ${ }^{258}$ Also, if an online service provider is suddenly liable for its users violating trademark laws, the online auction sight might decide to remove anything and everything that could be an infringing item. ${ }^{259}$ Removing these items might be" $[\mathrm{t}]$ hat slippery slope [which] will turn service providers into censors, potentially leading to removal of creative and lawful online conduct and speech." 260 Tiffany, like all retailers and distributors, would like the opportunity to control the distribution channel. ${ }^{261}$ However, if this decision had gone the other way, it could have led brand owners to be less vigilant about their trademarks and more vindictive towards online marketplaces that did not, or could not, remove all possibly infringing items. ${ }^{262}$

\section{The Virtue of the French Decision}

Though eBay was outraged over the Louis Vuitton decision, LVMH

255. Id.

256. Eric Goldman, Tiffany v. eBay District Court Opinion Analysis (Feb. 29, 2008 22:30 EST), http://blog.ericgoldman.org/archives/2008/07/tiffany_v_ebay_1.htm.

257. Jewelry Company Quest to Expand Trademark Law Could Quash Internet Commerce, U.S. FED. NEwS (Dec. 4, 2008), available at 2008 WLNR 23390608.

258. Brief for Amazon.Com, Inc., Google Inc., Information Technology Association of America, Internet Commerce Coalition, Netcoalition, United States Internet Service Provider Association, and United States Telecom Association as Amici Curiae in Support of DefendantAppellee [eB]ay, Inc., Tiffany (NJ) Inc. and Tiffany and Company v. eBay Inc., Dec. 2, 2008, http://www.eff.org/files/filenode/tiffany_v_ebay/amazonetalamicus.pdf.

259. Law Updates.com, Oliver A. Taillieu \& D. Dennis La, Esq., Tiffany v. eBay: A Trademark Owner Must Police Its Own Marks on the Internet, Sept. 26, 2008, http://www.lawupdates.com/commentary/itiffany_v_ebay_i_a_trademark_owner_must_police_it s_own_marks_on_the_intern.

260. Id.

261. See Should Online Marketplaces be the Trademark Police?, Nov. 14, 2007, http://blog.netchoice.org/2007/11/should-online-m.html.

262. Id. 
brought up major deficiencies in the eBay auction model. For example, even if eBay caught a counterfeit seller, "it is easy for the traders caught out to do exactly the same again using a different name."263 Approximately 178 infringing sellers relisted infringing items after eBay caught them selling those goods, demonstrating that eBay did not (or could not) take the proper steps to stop its service to those specific infringers. ${ }^{264}$ Without requiring a social security number or another unique identifier, counterfeit sellers could keep changing personal information and eBay would be none the wiser.

Beyond just controlling the sellers, a French judge gave an example of how eBay could control the actual sale of counterfeit goods: "the company should consider asking for the certificates of authenticity and serial numbers of luxury goods items for sale on its site to make sure the goods are genuine."265 Another suggestion was requiring sellers to guarantee that products offered for sale were authentic, or, after the first violation of selling counterfeit products, permanently closing the account of any offender. ${ }^{266}$ The French judge did not require eBay to take greater steps in preventing counterfeit sales at this time, but his comments suggest that French courts may apply higher standards to eBay in the future. ${ }^{267}$

The next major deficiency, according to the French court, was that eBay's anti-counterfeiting model required companies to financially contribute to eBay's VeRO program. ${ }^{268}$ LVMH was upset that its company, and other similar companies, would constantly be spending tremendous resources and time policing an online auction website they have no control over. ${ }^{269}$ The French court explained that eBay should not be permitted to ask companies to contribute financially when they are the victims of counterfeiting. ${ }^{270}$ In fact, according to LVMH, ninety percent of the Louis Vuitton bags and Christian Dior perfumes sold on eBay are actually fakes ${ }^{271}$ and profits have been hurt by the sale of these fake goods. ${ }^{272}$ Such a large percentage of fake items,

263. Watchdog Buys Counterfeit Goods from eBay's 'Most Trusted' Sellers, BBC (June 11, 2006), available at http://www.bbc.co.uk/pressoffice/pressreleases/stories/2006/11_november/ 06/watchdog.shtml.

264. Elizabeth Varner, Tiffany Inc. v. Ebay [sic], Inc.: Justice White's Outdated Guide to Trademark Infringement will Likely Result in Appeals, 11 TUL. J. TECH. \& INTELL. PROP. 157, $173(2008)$.

265. Louis Vuitton, Tribunal de commerce [T. Com.] [Commercial Court of Paris] Paris, June 30, 2008, RG 2006077799 (Fr.), at 7 available at http://www.qbpc.org.cn/uploads/ download/LVM\%20vs\%5B1\%5D.\%20eBay\%20Paris\%20Commercial\%20Ct\%20Decision.pdf.

266. Id.

267. See Richard Waters, Ebay [sic] Hammered on Fake Luxury Goods, FIN. TIMES (July 1, 2008), available at $\mathrm{http}: / / \mathrm{www} . \mathrm{ft} . \mathrm{com} / \mathrm{cms} / \mathrm{s} / 0 / 86254028-4707-11 \mathrm{dd}-876 \mathrm{a}-0000779 \mathrm{fd} 2 \mathrm{ac} . \mathrm{html}$ ? nclick_check=1.

268. See Louis Vuitton, RG 2006077799 at 10.

269. Id. at 12 .

270. Id.

271. Carvajal, supra note 11.

272. Suzy Jagger, EBay [sic] Braced for Wave of Copycat Lawsuits over Internet Fakes, ThE TIMES (July 2, 2008) at 42, available at http://business.timesonline.co.uk/tol/ 
according to some sources, are not entirely covert; in fact, it is downright obvious. An example of the blatant counterfeiting on eBay, there was one day where shoppers could pick from more than 2,500 "supposedly genuine" Louis Vuitton handbags; the company's French site, by contrast, listed just $80 .{ }^{2273}$ If only ten percent of items sold on eBay are genuine, LVMH did not see how contributing financially would stop the sale of counterfeit goods.

Shoppers are also not silent about receiving fake products. Currently, as many as 125 consumers have filed complaints with eBay because the believed the Tiffany items they purchased are counterfeits. ${ }^{274}$ The combination of blatant counterfeit sales and consumer complaints puts some of the onus on eBay and not the trademark owner. Because fake merchandise is so readily available to consumers, it does not seem unreasonable to take inexpensive measures to enhance the security on eBay's website.

eBay's motivation to combat counterfeiting might be suspect, given that it makes a profit from each sale. Even though trademark owners are vigorously fighting and spending money to stop the sale of their counterfeit products, eBay is making a profit off of those sales because "[e]Bay takes a small percentage of the value of every sale on its site, as well as a flat fee, and thus earns money from counterfeits sold on its site as well as genuine items.,"275 Though eBay reports that less than one in every 10,000 items generates a fraud complaint, ${ }^{276}$ the company listed 1.7 billion items in 2005 , meaning that "eBay averages more than 460 fraudulent listings every 24 hours -- each of which can stay active for days and snare multiple buyers." ${ }^{, 277}$ Selling 1.7 billion items adds up to a lot of transaction fees, and the French were rightly upset at eBay's conflict of interest because stopping the sale of counterfeit goods on eBay means that the company loses commissions.

With the combination of eBay's lack of control over sellers, making companies financially contribute to a business model they have no control over, and the collection of commission off of counterfeit products, it is not surprising that the French court believed their LVMH decision was justified. The French eBay site blatantly marketed and sold products that were counterfeit, and the explanation that they were merely a site host that facilitated transactions was not a good enough reason for the French to relieve eBay of liability.

business/industry_sectors/retailing/article4251692.ece.

273. Waters, supra note 267.

274. Tiffany Inc. v. eBay, Inc., 576 F. Supp. 2d 463, 487 (S.D.N.Y. 2008).

275. eBay's Legal Woes Handbagged, THE ECONOMIST (June 19, 2008), available at http://www.eiu.com/index.asp?layout=ib3Article\&article_id=1623470147\&country_id=\&pubty peid $=1$ 122462497\&industry_id=\&company_id $=380070438 \&$ channel_id $=\& \mathrm{rf}=0$.

276. Jim Wyss, Cyber-Sleuth Making a Bid to Wipe out Scams on Ebay: A Miami Springs Man has made it His Mission to Ferret Out Online Thieves and Scammers on eBay, MLAMI HERALD (Sept. 16, 2005), available at 2005 WLNR 14585049.

277. Id. 


\section{B. How These Polarized Decisions Will lead to International Forum Shopping}

One of the United States' leading intellectual property lawyers predicted that Louis Vuitton's victory over eBay could possibly prompt designers to start a chain of lawsuits looking to stop the sale of their fake goods on the Internet. ${ }^{278}$ Since the French court determined they had jurisdiction over French eBay, this could set off a chain of French luxury brands, or any trademark holder who meets French jurisdictional criteria, engaging in international forum shopping. Forum shopping is the process by which a plaintiff chooses among two or more courts that have the power--technically, the correct jurisdiction and venue-to consider his case. This forum decision is based on which court is likely to consider the plaintiff's case most favorably. ${ }^{279}$

Plaintiffs could consider the most favorable jurisdiction to their case, and would unlikely be hampered by an Internet server's location. The way that the Internet's hardware and software structure is designed ignores, rather than acknowledges, a geographic location. ${ }^{280}$ Therefore, "[i]t is easy to understand the unique problem that the Internet poses in jurisdictional matters ... [because] [ $t$ ] he very infrastructure of the internet makes it difficult to determine some facts fundamental to the exercise of jurisdiction."281 There is a lack of geographic boundaries on the internet. ${ }^{282}$ Businesses are aware of this difficulty but are unlikely to cut off domestic e-commerce business simply to avoid international liability. ${ }^{283}$ Businesses have already begun to try and geographically limit access to their online commercial offerings through measures like click-wrap agreements or software bars, albeit not that successfully. ${ }^{284}$

Due to a lack of geographical boundaries, the Louis Vuitton ruling could "encourage a number of other designers to sue eBay as well."285 Additionally, eBay might become more vulnerable to counterfeit claims outside of the luxury goods market because the Louis Vuitton decision set the precedent for all trademark owners, not just luxury goods owners. ${ }^{286}$ It may become very

278. Jagger, supra note 272.

279. Nolo.com, http://www.nolo.com/definition.cfm/Term/6A51B5C1-469D-4D5EBBFB579BBFB0496C/alpha/F/ (last visited Mar. 8, 2009).

280. Brian D. Boone, Bullseye!: Why a "Targeting" Approach to Personal Jurisdiction in the E-Commerce Context Makes Sense Internationally, 20 EMORY INT'L L. REV. 241, 246 (2006).

281. Id. at 245 .

282. Id.

283. Id. at 249-50. Germany is another potential location favorable to trademark owners. See supra notes 16-17 and accompanying text.

284. Boone, supra note 280, at 249-50.

285. Jagger, supra note 272. See also Carvajal, supra note 11.

286. Vidya Ram, eBay Branded by French Ruling, ForBES (June 30, 2008), available at http://www.forbes.com/2008/06/30/ebay-lvmh-closer-markets-equity-cx_vr_mp_0630 markets46.html. 
expensive for eBay to run international online auction sites if other countries have the same jurisdictional criteria as France, making eBay liable if their online auction site is directed at the country's population and is the place where the counterfeit harm occurs. ${ }^{287}$ eBay could be constantly litigating matters across the globe, which might eventually run the company into the ground. Though there is no indication that the Louis Vuitton decision was anything more than a protection of French trademarks, such a judgment of this type of litigation could lead other trademark owners to believe they could be successful as well.

\section{Potential SOLUTIONS}

The most practical solution to these polarized decisions would be for the United States and France to harmonize their online auction site trademark laws and policies in the appeals process of these cases. Not only would this make it easier for eBay and other online retailers to conduct business internationally, but it would also cater to the general long-term goals of trademark owners to seek uniformity in worldwide trademark laws. ${ }^{288}$ Due to globalization, it is imperative to harmonize international trademark laws and procedures because greater uniformity of these laws will "reduce costs, expedite registration and help ease administrative burdens on trademark owners."289 Treaties, use of model templates, and the passage of preemptive legislation are all means available to harmonize trademark laws. ${ }^{290}$ This, however, is a lofty goal. Organizations such as INTA have created a model anti-counterfeiting bill to harmonize laws, ${ }^{291}$ and perhaps it will take an entity like INTA to harmonize worldwide trademark laws. It is also important to note other countries in Europe may not follow France's lead in favoring trademark owners. ${ }^{292}$ Despite efforts to harmonize trademark laws across the European Union, ${ }^{293}$ it has not yet occurred. Therefore, since harmonization of international trademark laws is unlikely to happen anytime soon, it is important to find some realistic solutions to the counterfeit problem on online auction sites that will appease both sides.

287. Id. See Louis Vuitton, Tribunal de commerce [T. Com.] [Commercial Court of Paris] Paris, June 30, 2008, RG 2006077799 (Fr.), at 2, available at http://www.qbpc.org.cn/uploads/ download/LVM\%20vs\%5B1\%5D.\%20eBay\%20Paris\%20Commercial\%20Ct\%20Decision.pdf (finding that Article 46 allows a party to use the jurisdiction of the place where the damaging fact occurred or the place where the damage has been suffered, jurisdiction was deemed proper in France).

288. Kimbley Muller, INTA and Model Law/Examination Guidelines, 93 TMR 141 (2003).

289. INTA, Harmonization, http://www.inta.org/index.php?option=com_content\&task= view\&id=130\&Itemid=146\&getcontent $=3$ (last visited Apr. 26, 2009).

290. Muller, supra note 288.

291. See INTA, Model State Anti-Counterfeiting Bill: An Act to Provide for the Protection of Trademarks against Counterfeiting, http://www.inta.org/index.php?option=com_content\& task=view\&id=1439\&Itemid=146\&getcontent=3 (last visited Apr. 26, 2010).

292. Keenan, supra note 111.

293. Id. 
It is undeniable that fraudulent activity occurs on online auction sites. The question is what practical, reasonable steps can be taken to curb the counterfeiting and how online auction site policies and regulations can be amended to require these changes. This is a straightforward argument about whether "online auction sites should be pro-active in policing the property being sold on their sites." 294 eBay has taken measures to prevent fraudulent behavior, but is it enough? Though shoveling all the liability on online auction sites is not the solution, eBay should not be given a get out of jail free card for hosting illegal counterfeit activity. Greater, more cost-efficient measures need to be implemented by eBay to curb behavior that forces brand owners to police their trademarks so inefficiently. ${ }^{295}$ Additionally, some responsibility must be placed on the consumer, because counterfeiting luxury goods would not exist if there were not a market to purchase them.

\section{A. Making the Online Auction Site more Liable}

The main problem with placing all trademark policing responsibilities onto the trademark owner is the potential for willful blindness from eBay. Since online auction sites make a profit off of counterfeit sales, there may not be an incentive to be as diligent in removing counterfeit items. If online auction sites were only responsible for "general" anti-counterfeiting measures, they might fail to investigate specific infringement, even though the online auction site might have the knowledge that specific trademarks were being infringed. ${ }^{296}$

eBay's conflict of interest between stopping counterfeit activities and making a profit becomes more apparent the further one digs into its business practices. In the Tiffany case, eBay recognized and admitted that its "buyers [were] very interested in brands" 297 and in order to attract potential buyers to its website, eBay dedicated a significant amount of time to assisting the growth of eBay sellers in the Jewelry \& Watches category. ${ }^{298}$ In fact, eBay considered itself to "be a competitor of Tiffany and the principal source of 'value' pricing of Tiffany jewelry," and eBay "regularly conducted promotions to increase bidding on auctions and to increase sales of fashionable and luxury brands, including Tiffany." 299 Though the New York court did not find this information detrimental to eBay, on a broader scale it is detrimental to

294. See Adrian Portlock, CheckMEND Service Addresses Online Auction Sites' Problems: Need for Stronger Solutions Underscored by eBay Counterfeits Ruling in France; US [sic] Decision Imminent, http://blog.recipero.com/category/checkmend-usa/ (July 3, 2008).

295. See, e.g., Varner, supra note 264, at 172. ("[e]Bay was willfully blind to the trademark infringement on its Web site. The court's finding that eBay was not willfully blind because it conducted general anticounterfeiting procedures on its Web site is incorrect.").

296. See id. at 172 .

297. Tiffany Inc. v. eBay, Inc., 576 F. Supp. 2d 463, 480 (S.D.N.Y. 2008).

298. Id.

299. Id. 
trademark brand owners. Because eBay used the phrase "value pricing," it is puzzling how the court applauded their anti-counterfeiting measures when Tiffany's "About Me" page and business practice advised consumers the sale of products is tightly controlled and that there is never value pricing. ${ }^{300}$ Making an online auction site more prone to liability might provide an incentive for online auctions to police their markets more carefully. ${ }^{301}$

Nevertheless, "while it may be tempting to force eBay into changing its business practice to better suit intellectual property rights owners, it is unlikely to have any long-term effect on an issue which really needs a well-structured rights protection regime to resolve." 302 eBay can implement some wellstructured measures as a site host to further reduce the sale of counterfeit goods without completely revamping its online auction website. First, eBay can force consumers to check a disclaimer box every time a bid is placed indicating that the sale might not be authentic. Additionally, it could include a disclaimer saying that the only way to assure a genuine product is to purchase the product from the brand owner itself, and the consumer risks the chance of buying a counterfeit item. eBay can prompt the consumer to go to the "About Me" pages, ${ }^{303}$ which list the manufacturers and, if the consumer desires, he or she can contact the manufacturer to make sure the item being purchased is indeed genuine. $^{304}$

Another possible solution is not allowing the sale of brand new luxury items on eBay, or, if there were brand new items sold, the luxury brand owner would be the exclusive seller. This would allow products to be authenticated either directly on the online auction site, or by some other means, such as a verification e-mail from the manufacturer or eBay. Non-manufacturer sellers, or consumers who are just re-selling products on eBay, could advertise the sale of products as "like new" or "unused," or comparable language, protecting both the consumer and the brand owner.

However, not everyone agrees that this type of authentication would be fruitful. "[I]f eBay [loses] its appeal in France it would likely have to reach an agreement with the luxury goods companies to track serial numbers," which would perhaps be too unwieldy and/or expensive, and eBay would lose all control of its pricing policy. ${ }^{305}$ In the worst case scenario, eBay might have to

300. See LaLonde, supra note 76 ("Tiffany sells its new silver Tiffany jewelry in the United States only in its retail stores or through its catalogs, web site or Corporate Sales Department; the court referred to its distribution chain as tightly controlled. It never sells overstock merchandise or puts its products on sale at lower prices.").

301. Varner, supra note 264 , at 174.

302. Actuate IP, supra note 68.

303. eBay did eventually provide a disclaimer for Tiffany, but eBay should perhaps implement this policy throughout the entire website for all brand owners. See Tiffany Inc., 576 F. Supp. 2d at 491 ("The warning message also provided a link to the Tiffany 'About Me' Page. If the seller continued to list an item despite the warning, the listing was flagged for review.").

304. See Tiffany Inc., 576 F. Supp. 2 d at 491.

305. Ram, supra note 286. 
give up selling certain luxury lines altogether. ${ }^{306}$

Despite concerns, this type of sales model has already been implemented with the website Portero.com. ${ }^{307}$ Portero.com provides shoppers with the security of having the items sold authenticated, therefore removing the concern of selling counterfeit goods for both the consumer and the retailer. ${ }^{308}$ This idea of having a portion of eBay that exclusively sells luxury goods authenticated by trademark brand owners is an option that could cut down the cost of litigation and uncertainty facing the online auction website today. ${ }^{309}$ Having a portion of the online auction site allow for authentication should not be anymore burdensome to the online auction site than the twenty-million already spent ${ }^{310}$ in combating counterfeit practices.

However, what message does that send to the world in terms of keeping the Internet free and open to force an online platform to take responsibility for counterfeited goods? Take the Global Online Freedom Act of 2008, the goal of which was "to use United States influence - both governmental and commercial - to advance Internet freedom in repressive regimes." ${ }^{11}$ Making an online auction site more liable might force countries around the world into censorship and surveillance of the internet to avoid lengthy lawsuits and counterfeit goods from flowing freely across borders. ${ }^{312}$ Though this Act is meant to focus on political freedom of the internet, countries could easily use this ability to block websites for counterfeit goods as a political platform. The European Union sees censorship as a trade barrier. ${ }^{313}$ Therefore, blocking

306. Id.

307. See Portero.com, http://www2.portero.com/about-portero (last visited Apr. 26, 2010) ("[Portero Luxury]'s collection of certified pre-owned, vintage and collectible merchandise including handbags, watches, jewelry and accessories - features brands such as Chanel, Hermès and Rolex. Since 2004, Portero Luxury's core values of customer service and guaranteed authenticity have placed it at the forefront of online luxury retailers.") [hereinafter About Portero.com]. See also Kathryn Tuggle, Strange Ways to Get out of Debt, FOXBusiness.com (Oct. 27, 2008), available at http://www.foxbusiness.com/story/personal-finance/ontopic/debt/strange-ways-debt-work/ ("At www.Portero.com, an online auction house for luxury items like jewelry and accessories, individuals can sell items that range in cost from $\$ 400$ to $\$ 50,000 . ")$.

308. See About Portero.com, supra note 307 ("In certain cases [Portero.com] partner[s] with selected brands (such as Kwiat, Lalique, and Robert Lee Morris) or retailers (such as Tourneau) to assist in certifying authenticity, and those partnerships are noted in the item listing.").

309. See Portero.com, Authenticity, http://www2.portero.com/authenticity (last visited Mar. 7, 2009) ("We determine authenticity by drawing on the experience of our in-house category specialists, by working with outside product experts, and in some cases by partnering with selected luxury brands and other leading luxury companies . ...").

310, Tiffany Inc. v. eBay, Inc., 576 F. Supp. 2d 463, 4766 (S.D.N.Y. 2008).

311. Center for Democracy and Technology, Analysis of the Global Online Freedom Act of 2008 [H.R. 275]: Legislative Strategies to Advance Internet Free Expression and Privacy Around the World (May 2, 2008), available at http://www.cdt.org/international/ censorship/20080505gofa.pdf.

312. Id.

313. Eric Bangeman, EU May Begin Treating 'Net Censorship as a Trade Barrier, http://arstechnica.com/news.ars/post/20080227-eu-may-begin-treating-net-censorship-as-a- 
internet sites is not the answer, but regulating their content and how goods are sold is a more practical and cost-effective solution.

\section{B. Focus more on Consumer Education}

Although these decisions have focused primarily on the liability of the online auction site and the trademark owner, perhaps it should be recognized that more responsibility needs to lie with the consumer. At some point, online auction sites and luxury brand owners have no recourse if consumers are unwilling to cooperate and continue buying luxury knock-offs. Counterfeiters know that consumers crave cheap luxury goods, and as soon as a new design comes out, counterfeiters around the globe churn out fake versions and have no trouble selling them. ${ }^{314}$ Shoppers pick up these knock-offs for one-tenth of the cost and then pass off the good as genuine. ${ }^{315}$

Consumers around the globe do not seem to grasp the implications of buying a counterfeit good. For instance, in the United Kingdom ("UK") in 2006, twentyeight percent of the UK population purchased a genuine designer item, yet in the same year, about three million people bought a fake luxury item. ${ }^{316}$ Consumers see fake items as "bargains," and in the UK sixty-four percent of people admitted to friends and colleagues that their "genuine" item was not real." ${ }^{317}$ Perhaps if consumers were better informed as to the criminal links in counterfeiting and the potential implications of buying a counterfeit good, ${ }^{318}$ the fashion industry might have a chance of beating the counterfeiters. ${ }^{319}$

Similarly, in the United States, "one in four people in Los Angeles County knowingly bought, copied, or downloaded illegal goods in the last year." 320 Those who purchased these goods viewed their purchase of these products as a victimless crime. ${ }^{321}$ Most consumers do not know that the sale of counterfeit T-shirts may have helped finance the 1993 World Trade Center bombing, ${ }^{322}$ or that counterfeiting profits are one of the main sources of income supporting international terrorism. ${ }^{323}$ Counterfeiting schemes are run by criminal organizations also dealing in narcotics, weapons, child prostitution,

trade-barrier.html (Feb. 27, 2008, 11:07 EST).

314. Dana Thomas, Terror's Purse Strings, N.Y. Times(Aug. 30, 2007) at A23, available at http://www.nytimes.com/2007/08/30/opinion/30thomas.html.

315. Id.

316. Melinda Oliver, Give Fakers a Reality Check, DrAPERS (Nov. 17, 2007), available at http://www.drapersonline.com/news/give-fakers-a-reality-check/291987.article.

317. Id.

318. See supra text accompanying notes 55-59.

319. Oliver, supra note 316.

320. Richard Verrier, Fake Goods come Easy, Survey Finds - One in four Angelenos Knowingly buy Pirated Products because they are Cheap and Easily Attainable, Study Shows, L.A. Trmes (Aug. 20, 2007) at Business, available at http://articles.latimes.com/2007/ aug/20/business/fi-counterfeit20.

321. Counterfeit Bags May Have Links To Organized Crime, Terrorism, WISN.com (May 8, 2003) http://www.wisn.com/news/2191330/detail.html.

322. LaLonde, supra note 76.

323. Id. 
human trafficking, and terrorism. ${ }^{324}$

Consumers need to stop focusing on the goods and start focusing on the merchants. Instead of choosing bad merchants they need to be able to identify the good merchants ${ }^{325}$ by either researching who they are purchasing goods from or informing online auction sites that they are unsure of a seller. Luxury brands also need to do a better job teaching the consumer about what is and is not genuine. ${ }^{326}$ If consumers stop knowingly buying fakes, the supply chain will dry up and counterfeiters will go out of business. ${ }^{327}$ None of this is possible without collaboration between the online auction site, luxury brand owners, and consumers alike.

\section{CONCLUSION}

Counterfeit litigation regarding the policing of trademarked goods is far from over for eBay. eBay still plans on appealing the ruling of the French court, $^{328}$ and Tiffany still plans on appealing the New York District court's decision, as well. ${ }^{329}$ Interestingly, the United States court did not decide whether eBay or Tiffany was more capable of stopping the sale of counterfeit goods on eBay, calling it an "open question left unresolved by this trial." Perhaps the appeal will shed more light on this question.

Additionally, even if the United States requires eBay to implement more stringent procedures on its online auction site, there is no guarantee that the sale of counterfeit goods will not migrate to other online auction sites, ${ }^{331}$ or that France will believe the United States is being stringent enough. Not all online

324. Id.

325. Brown, supra note 27

326. LaLonde, supra note 76.

327. Id.

328. See, e.g., Matheson Ormsby Prentice, [e]Bay - A Fashion Victim in On-Line Coiunterfeiting [sic] Cases, Sept. 2008, http://www.mop.ie/dynamic/files//P\%20 Ezine\%20EBAY\%20A\%20fashion\%20victim\%20in\%20on-line\%20counterfeiting\%20cases $\%$ 20September\%202008.pdf, predicting that: On appeal eBay is likely to challenge the finding in relation to the alleged breach of LVMH's exclusive distribution network on the basis that any product put freely on the EU market by the right holder may be bought and resold by anyone else as long as it does not infringe trademark rights. It will also challenge the Court's conclusion that eBay was a broker under the E-commerce [sic] Directive. If this appeal is unsuccessful the decisions could have considerable impact on on-line [sic] auction websites as those businesses will have an obligation to monitor products sold and to increase control over users.

329. See Bennet Kelley, Measuring the 110th Congress at Twilight, 12 No. 4 J. INTERNET L. 25 (2008); Jeff Meisner, Tiffany Keeps Hammering at eBay Lawsuit, E-COMMERCE TMES, Aug. 8, 2008, http://www.ecommercetimes.com/story/64131.html?wlc=1236454181.

330. See LaLonde, supra note 76 ("It appears that Tiffany was in the best position to know if specific listings offered counterfeit goods because its employees have the expertise to determine whether listed goods were counterfeit and eBay was in the best position to warn its sellers not to counterfeit, to educate them on counterfeiting and its consequences, and to delete listings and suspend sellers.").

331. Rob Bates, Ebay [sic] Case: Tiffany Knocked out over Knock Offs, JCKONLINE.COM, July 15, 2008, http://www.jckonline.com/blog/870000287/post/1640029964.html. 
sites that sell goods have invested as much time and money into fighting counterfeit goods as eBay. ${ }^{332}$ It is important that reasonable safety measures be put in place to help regulate the sale of goods on all online auction sites. Therefore, the appeals to the United States and French eBay decisions must broadly implicate all online auction sites, not just eBay. Pursuing litigation on all online auction sites is not economical, since some smaller, less efficient websites will not be as diligent as eBay in their anti-counterfeiting measures. ${ }^{333}$

Without harmonizing online auction site regulations, international forum shopping might occur with luxury brand owners suing online auction sites to recover large damages awards, countries might begin censoring (blocking) online auction sites to avoid lengthy litigation, and consumers will still lose out in the end. With no harmonization on the horizon and no resolution as to whether online auction sites are responsible for policing trademarks, it could be the end of open online auction internet sales between France and the United States, and the beginning of strained relationships between eBay and other countries with similar jurisdictional criteria as France.

Ultimately, harmonization of online auction site regulations comes down to whether other countries are likely to believe that online auction sites such as eBay are more akin to a traditional retail store, or merely an online facilitator between buyers and sellers. ${ }^{334}$ Realistically, with 3.5 million new auctions every day, it would be impossible for eBay to police every sale. ${ }^{335}$ eBay is a marketplace, not a retailer, and it does not own or take possession of any of the products. ${ }^{36}$ There is no way for eBay to know whether something violates trademark rights unless the rights' owners themselves inform eBay. ${ }^{337}$ eBay cannot be willfully blind to violations, but having a zero-tolerance policy across the globe for stopping counterfeit goods is also unrealistic for online auction sites.

The courts must be aware that policing trademarks is a difficult task. Ultimately, the United States must implement more stringent policies for online auctioneers to ensure the authenticity of the goods sold and create a safer environment for consumers. Online auction sites are in the best position to install measures on their individual sites to help combat the sale of counterfeit goods. Though there is no easy solution, this area of the law will continue to evolve in the coming years, optimistically in a manner that ultimately protects consumers and trademark holders alike. ${ }^{338}$

332. See Richard, supra note 3 ("There are many Web sites that advertise products that purport to be the genuine article that are not.").

333. See Bates, supra note 331.

334. Braden Cox, Should Online Marketplaces be the Trademark Police?, Nov. 14, 2007, http://techliberation.com/2007/11/14/should-online-marketplaces-be-the-trademark-police/.

335. AJ Park, Brand Owners Versus eBay, Aug. 15, 2008, http://www.ajpark.com/articles/ 2008/08/brand_owners_versus_ebay.php.

336. Id.

337. Id.

338. See, e.g., Clayton, supra note 149 ("This area of law will continue to evolve, as courts apply (or change) principles of secondary liability developed decades before the establishment of the Internet."). 